\title{
Chemical characterisation and determination of sensory attributes of hydrolysates produced by enzymatic hydrolysis of whey proteins following a novel integrative process
}

Article

Accepted Version

Welderufael, F. T., Gibson, T., Methven, L. and Jauregi, P. (2012) Chemical characterisation and determination of sensory attributes of hydrolysates produced by enzymatic hydrolysis of whey proteins following a novel integrative process. Food Chemistry, 134 (4). pp. 1947-1958. ISSN 03088146 doi: https://doi.org/10.1016/j.foodchem.2012.03.113 Available at https://centaur.reading.ac.uk/27949/

It is advisable to refer to the publisher's version if you intend to cite from the work. See Guidance on citing.

Published version at: http://dx.doi.org/10.1016/j.foodchem.2012.03.113

To link to this article DOI: http://dx.doi.org/10.1016/j.foodchem.2012.03.113

Publisher: Elsevier

All outputs in CentAUR are protected by Intellectual Property Rights law, including copyright law. Copyright and IPR is retained by the creators or other copyright holders. Terms and conditions for use of this material are defined in the End User Agreement. 


\section{www.reading.ac.uk/centaur}

\section{CentAUR}

Central Archive at the University of Reading

Reading's research outputs online 
Chemical characterisation and determination of sensory attributes of hydrolysates produced by enzymatic hydrolysis of whey proteins following a novel integrative process

Fisseha Tesfay Welderufael $^{\mathrm{a}}$, Trevor Gibson ${ }^{\mathrm{b}}$, Lisa Methven ${ }^{\mathrm{a}}$ and Paula Jauregi ${ }^{\mathrm{a}}$

${ }^{a}$ Department of Food and Nutrition Sciences, The University of Reading, Reading, United Kingdom.

${ }^{b}$ BioCentre Facility, The University of Reading, Reading, United Kingdom,

* Corresponding author:

Paula Jauregi

Reading University

Department of Food and Nutrition Sciences

Reading, United Kingdom

$\mathrm{Tel}+44(0) 1183788728$,

PO Box 226,

E.mail address:p.jauregi@reading.ac.uk 


\section{ABSTRACT}

4 The overall aim of this work was to characterize the major angiotensin converting 5 enzyme (ACE) inhibitory peptides produced by enzymatic hydrolysis of whey 6 proteins, through the application of a novel integrative process. This process 7 consisted of the combination of adsorption and microfiltration within a stirred cell 8 unit for the selective immobilization of $\beta$-lactoglobulin and casein derived peptides 9 (CDP) from whey. The adsorbed proteins were hydrolyzed in-situ which resulted in 10 the separation of peptide products from the substrate and fractionation of peptides. 11 Two different hydrolysates were produced: (i) from CDP $\left(\mathrm{IC}_{50}=287 \mu \mathrm{g} / \mathrm{mL}\right.$ ) and (ii) 12 from $\beta$-lactoglobulin $\left(\mathrm{IC}_{50}=128 \mu \mathrm{g} / \mathrm{mL}\right) . \mathrm{IC}_{50}$ is the concentration of inhibitor needed 13 to inhibit ACE by half. The well known antihypertensive peptide IPP and several 14 novel peptides that have structural similarities with reported ACE inhibitory peptides 15 were identified and characterized in both hydrolysates. Furthermore, the hydrolysates 16 were assessed for bitterness. No significant difference was found between the control 17 (milk with no hydrolysate) and hydrolysate samples at different concentrations (at, 18 below and above the $\mathrm{IC}_{50}$ ). The $\mathrm{IC}_{50}$ is the concentration of peptide needed to inhibit 19 ACE by half.

Keywords: ACE inhibitory peptides, $\beta$-lactoglobulin, Casein derived peptides, ion exchange resin, protease $\mathrm{N}$ 'Amano', bitterness.

\section{Introduction}

ACE inhibitory peptides derived from natural sources such as whey proteins could be used to prevent and help to treat hypertension by dietary intervention. Several animal model and human trial studies have demonstrated the antihypertensive effect of ACE 
inhibitory peptides derived from milk proteins (Abubakara, Saito, Kitazawa, Kawai \& Itoh, 1998). Some fermented milk products and hydrolysates containing ACE inhibitory peptides from milk proteins are already in the market (Korhonen \& Pihlanto, 2006).

In recent years, several sequences of bioactive peptides from natural sources including peptides from $\beta$-lactoglobulin and casein derived peptides that can inhibit ACE activity have been discovered (Jauregi, 2008; Jauregi \& Welderufael, 2010; OrtizChao et al., 2009; Pihlanto-Leppala, Koskinen, Piilola, Tupasela \& Korhonen, 2000). ACE, which is a constituent part of the rennin-angiotensin system, is a widely accepted enzyme and is considered as the first line of therapy to treat hypertension (Coppey et al, 2006). The first ACE inhibitory peptide was isolated from snake venom (Ferreira, 1965) and most antihypertensive drugs such as, captopril, lisinopril and enalapril that can block the ACE mediated production of angiotensin II were designed based on the snake venom peptide scaffold. The inactivation of ACE also results in an increase in the nonapeptide bradykinin which is a vasodilator. Because of these dual vascular and endothelial protective mechanism of ACE inhibition, the production of nitric oxide is stimulated, vascular smooth muscle is relaxed and fibrinolysis is increased (Ceconi, Francolini, Olivares, Comini, Bachetti \& Ferrari, 2007).

ACE has two biologically active substrates: a decapeptide angiotensin I (Asp-ArgVal-Tyr-Ile-His-Pro-Phe-His-Leu) and a nonapeptide bradykinin (Arg-Pro-Pro-GlyPhe-Ser-Pro-Phe-Arg). Cheung and co-authors (1980) reported the importance of the 

peptides Hippuryl-Histidyle-Leucine (Hip-His-Leu) and Hippuryl-PhenylalanineArginine (Hip-Phe-Arg) that have similar C-terminal di-peptides with that of angiotensin I and bradykinin. They reported that these two peptides had similar binding affinity trends as angiotensin I and bradykinin, hence indicating substrate specificity of ACE.

ACE has specificity for smaller peptides up to 12 amino acids in length with hydrophobic and positively charged amino acids at the C-terminal end (Cheung et al., 1980; Mullally, Meisel \& FitzGerald, 1997b; Nakamura, Yamamoto, Sakai, Okubo, Yamazaki \& Takano, 1995). Wu and co-authors (2006) also recently reported the most favorable structure-function relationship of di- and tri-peptide sequences for potent ACE inhibition; di-peptides with amino acids with bulky and hydrophobic side chains are more favorable while tri-peptides with aromatic amino acids at the carboxyl end, hydrophobic amino acids in the amino terminus and positively charged in the middle are more favorable. In addition to their amino acid composition and sequences, peptides have to be able to resist the gastrointestinal digestion in order to be absorbed and pass to the circulatory system so that they can reach the peripheral organ in active form and exert its biological effect (Quiro's, Contreras, Ramos, Amigo $\&$ Recio, 2009).

Several processes have been proposed for the production of hydrolysates with ACE inhibitory activity based on fermentation and enzymatic hydrolysis of food proteins. However most of these either produce hydrolysates with complex mixtures of peptides or use further purification steps for enrichment purposes (see Table 1). We have developed an integrative process for the production of ACE inhibitory peptides from $\beta$-lactoglobulin and CDP (Welderufael and Jauregi, 2010: Welderufael, Gibson 
and Jauregi, 2012). This process has several advantages: it is simple as it avoids subsequent purification and enrichment steps; less complex hydrolysates are produced with high potency (i.e., low $\mathrm{IC}_{50}$ ); using the ion exchanger increases enzyme stability; it enables enzyme recycling. Moreover, it is well known that hydrolysis of casein results in many bitter peptides (Kilara \& Panyam, 2003) and often those amino acid sequences with high bioactivity are responsible for increased bitterness. Especially hydrophobic peptides with smaller molecular weight, less than $3 \mathrm{kDa}$, are the reason for this undesirable taste that hinders their incorporation into food products (Cheung \& Li-Chan, 2010).

The purpose of the current work was to characterise, identify and evaluate the structure-function relationship of the major peptides in the hydrolysates produced by the integrative process. The in-vitro stability of the hydrolysates was assessed by simulating the gastrointestinal digestion using pepsin and corolase PP. Moreover, the in silico digestion of the major peptides was carried out with pepsin, trypsin and chymotrypsin. Finally the sensory attributes of the hydrolysates in milk drinks were evaluated at different hydrolysate concentrations at, below and above their $\mathrm{IC}_{50}$.

\section{Materials and Methods}

\subsection{Materials and reagents}

Bovine $\beta$-lactoglobulin, N-Hippuryl - L - Histidyle - L - Leucine (HHL), $\alpha$ lactalbumin, bovine serum albumin (BSA), hippuric acid (HA), angiotensin converting enzyme (ACE; EC 3.4.15.1), bicinchoninic acid solution (BCA), coppersulphate solution and DEAE sepharose ${ }^{\circledR}$ were purchased from Sigma (Steinhein, Germany). Flat sheet microfiltration membranes $(0.45 \mathrm{~mm})$, potassium mono- 
105 phosphate, potassium di-phosphate, sodium chloride $(\mathrm{NaCl})$, trifluoroacetic acid

106 (TFA), acetonitrile, hydrochloric acid, and sodium hydroxide were purchased from

107 Fisher Scientific UK Limited. Glycerol from BDH laboratory supplies (England).

108 Food grade sodium mono-phosphate, sodium di-phosphate, sodium chloride $(\mathrm{NaCl})$

109 were purchased from Meridian star, United Kingdom. Protease N ‘Amano’ of Bacillus

110 subtilitis was obtained from Amano Enzyme Inc., Nagoya, Japan $(191,000$ units = gm)

111 where one unit of enzyme produces amino acids equivalent to 0.1 gm of tyrosine in 60

$112 \min$ at $\mathrm{pH} 7$ and a temperature of $55^{\circ} \mathrm{C}$. The preferred hydrolysis of this enzyme is at

113 the C-terminus of threonine, cysteine, methionine, phenylalanine and leucine (Ortiz

114 Chao 2008). Amicon filtration cell was obtained from Amicon a Grace company.

115 Syringe driven PVDF filter $(0.45 \mu \mathrm{m}$ and $0.2 \mu \mathrm{m})$ was obtained from Millipore

116 Corporation, Bedford, UK. Skimmed milk was obtained from a local retailer and all

117 other reagents and chemicals were analytical grade.

118

119

\subsection{Methods}

\subsubsection{Whey preparation}

Pasteurised skimmed milk was bought from the local supermarket and heated at $35{ }^{\circ} \mathrm{C}$. Then commercial rennet was added at $0.3 \mathrm{~mL} / \mathrm{L}$ and stirred gently for $1 \mathrm{~min}$. The milk was left for $1 \mathrm{~h}$ and then the casein coagulum was cut vertically ( $25 \times 25 \mathrm{~mm}$ ) with a knife to drain the lactoserum. Incubation was extended for 20 min after which the whey was scooped from the vessel and filtered using cheese cloth. The collected whey was stored at $-20{ }^{\circ} \mathrm{C}$ until used for further experiments.

\subsubsection{Hydrolysate production}




\section{Lab scale production of hydrolysates for chemical characterisation}

132 The hydrolysates were produced from $\beta$-lactoglobulin and CDP in sweet whey

133 following an integrative approach as described in our previous work (Welderufael

134 Gibson and Jauregi 2012). The integrative process consists of three main unit

135 operations: (1) ion exchange adsorption (2) hydrolysis and (3) microfiltration. These

136 unit operations were integrated within a stirred cell $(200 \mathrm{ml})$ fitted with a

137 microfiltration membrane where $10 \mathrm{~mL}$ of ion exchange adsorber were mixed with

$138100 \mathrm{~mL}$ of whey during 10 minutes. The non-adsorbed whey proteins were filtered.

139 Then selective hydrolysis of the bound proteins (CDP and $\beta$-lactoglobulin) was

140 carried out followed by microfiltration of the first hydrolysate product with peptides

141 mainly from CDP ( $4^{\text {th }}$ step). Two hydrolysates were produced from CDP, one after 2

142 hours hydrolysis and the second one after 6 hours hydrolysis (Fig 1). One $\beta$ -

143 lactoglobulin hydrolysate product was formed by first hydrolysing the bound proteins

144 for 2 hours, then filtering the resulting hydrolysate and extending the hydrolysis for a

145 further six hours with fresh enzyme $(2+6$ h hydrolysis in Figure 1$)$ followed by

146 microfiltration and recovery of the hydrolysate All hydrolysis reactions were carried

147 out with Amano $\mathrm{N}$ enzyme at $\mathrm{pH} 7,45^{\circ} \mathrm{C}$ and $\mathrm{E}: \mathrm{S}$ ratio of $1: 100$ and for the the $\beta$ -

148 lactoglobulin derived hydrolysate we also investigated the effect of reducing the E:S

149 ratio to 1:50. At the end of the hydrolysis the hydrolysates were fractionated using 1

150 kDa ultrafiltration membrane which yield two different hydrolysate products: P1 and

151 P2 with peptides derived from CDP. These hydrolysate products were further

152 fractionated with semi-prep RP-HPLC prior to MS analysis; the hydrolysate derived

153 from $\beta$-lactoglobulin (P3) was less complex hence it was directly injected into the

154 LC/MS/MS system. 


\section{Scaled up production of hydrolysates for sensory evaluation}

159 The hydrolysate production was scaled up to process $2 \mathrm{~L}$ of whey. The process was

160 the same as that describe above and in Figure 2 but was carried out in the pilot plant

161 with the larger equipment used for each unit operation. The ion exchange resin (200

$162 \mathrm{~mL}$ ) and whey (2 L) were mixed for $10 \mathrm{~min}$ with continuous stirring (400 rpm at room

163 temperature) in a stirred tank with a heating water jacket through which water is

164 circulating (2.5 L, Applicon Biotechnology, Holland) at room temperature. The

165 mixture was transferred to a feed tank and from there it was pumped into the filtration

166 unit which consisted of a cross flow filtration system (PCI Midi ultrafiltration Plant,

167 UK, Whiteley, Fareham) fitted with $0.22 \mu \mathrm{m}$ nitrocellulose microfiltration membrane

168 (Millipore Corporation, UK, Watford) by applying a pressure of $100 \mathrm{psi}$ at an average

169 flow rate of $10 \mathrm{~mL} / \mathrm{min}$. The non-adsorbed proteins went through and removed while

170 the retentate containing the resin, CDP and $\beta$-lactoglobulin were recycled back to the

171 reaction vessel. The hydrolysis process was carried out exactly at the same conditions

172 as in the lab scale experiments (see above). After 2 hours hydrolysis the mixture was

173 passed through the cross flow filtration system and the first hydrolysate product

174 containing mainly CDP derived peptides was collected in the permeate. The retentate

175 was recycled back to the reaction vessel and hydrolysis was resumed for 6 more hours

$176(2+6)$ by adding fresh enzyme at an $\mathrm{E}: \mathrm{S}$ ratio of 1:50 (as in lab scale process) to

177 produce the second hydrolysate containing mainly $\beta$-lactoglobulin derived peptides. 
$181 \quad$ 2.2.3. Micro QTOF electrospray ionisation tandem mass spectrometry (ESI MS/MS) for amino acid sequencing of peptides derived mainly from CDP at

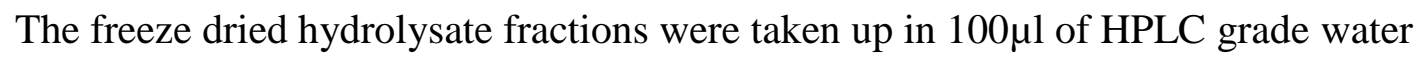
and then an aliquot diluted 1:1 in water containing $0.1 \%$ formic acid for infusion into the mass spectrometer. The mass spectrometer used was a Bruker MicroTOFQ II (Bruker Daltonic, Bremen, Germany) equipped with electrospray ionisation source. The samples were infused into the source, at $3 \mu \mathrm{L} / \mathrm{min}$, using a Harvard syringe pump equipped with a $100 \mu \mathrm{L}$ syringe. The mass spectrometer had previously been calibrated over a mass range of m/z 300-3000 using Agilent Tunemix ${ }^{\mathrm{TM}}$. As each spectrum appeared a major peptide mass was isolated and fragmented in the collision cell using sufficient energy to reduce the precursor ions to about $10 \%$ and to

194 produce an intense product ion spectrum. The accurate mass of each precursor ion was then used to predict a formula to within approximately $20 \mathrm{ppm}$ accuracy and that was used in combination with the MS/MS spectrum to obtain a partial or full amino acid sequence. Software used was Bruker sequence editor and Mass Analysis Peptide

198 Sequence Prediction (MAPSP).

199

2.2.4. LC-ESI/MS method for peptide identification in $\beta$-lactoglobulin hydrolysate

202 Peptides of $\beta$-lactoglobulin hydrolysate and peptides in sweet whey were analysed by 203 LC-MS. Samples were reconstituted in HPLC grade water (1:100) and $2 \mu$ L injected. 204 The peptides were separated using reverse phase liquid chromatography (RP-HPLC) 
with an Agilent 1100 HPLC system (Agilent Technologies, CA, USA). The column used was a Nova-Pak C18 column $(150 \times 2.1 \mathrm{~mm}$ i.d. $)$. A gradient solvent system was applied with eluent " $\mathrm{A}$ " as $0.1 \%$ formic acid in water and eluent " $\mathrm{B}$ " $0.1 \%$ formic acid

208 in acetonitrile. The flow rate was $0.2 \mathrm{~mL} / \mathrm{min}$ and, the column and the auto sampler

209 temperature were kept at 25 and $10{ }^{\circ} \mathrm{C}$ respectively. Eluent " $\mathrm{A}$ " was 98 to $55 \%$ for 45 min, 55 to $30 \%$ for $5 \mathrm{~min}$ and then kept at $30 \%$ for $5 \mathrm{~min}, 30$ to $98 \%$ for $5 \mathrm{~min}$ and

$21198 \%$ for 15 min. The peaks were identified using a Bruker MicroTof QII high

212 resolution TOFMS equipped with an electrospray ionisation (ESI) source. The ion

213 spray voltage was held at $4500 \mathrm{~V}$ in positive ion mode. The nebuliser gas was nitrogen

214 at a pressure of 1.0 bar; drying gas and temperature were $8 \mathrm{~L} / \mathrm{min}$ and $180{ }^{\circ} \mathrm{C}$

215 respectively. The instrument was interfaced to a computer running Bruker Data

216 Analysis software version 4 and data acquired over a mass range of 50-3000 Da.

\subsubsection{Determination of ACE inhibitory activity}

218 The ACE inhibitory activity of hydrolysates was measured following the HPLC based method by Hyun and Shin (2000) with some modifications as described in

220 Welderufael and Jauregi (2010). The enzymatic assay in this method was based on the 221 hydrolysis of the substrate, $5 \mathrm{mM}$ HHL in a $0.1 \mathrm{M}$ sodium phosphate buffer $(\mathrm{pH} 8.2)$

222 with $0.3 \mathrm{M} \mathrm{NaCl}$ by the $\mathrm{ACE}(60 \mathrm{mU})$ which resulted in the production of hippuric 223 acid (HA). The hippuric acid was determined by RP-HPLC) as described in 224 Welderufael and Jauregi (2010) using a Dionex HPLC system (Camberley, UK) that 225 consisted of, a P680 HPLC pump, ASI-100 automated sample injector, thermostatted 226 column compartment TCC-100 and PDA-100 photodiode array detector and a C18 227 column (Ace5 $250 \times 4.6 \mathrm{~mm})$. 
229 The percentage of ACE inhibitory activity (ACEi \%) was calculated based on the

230 hippuric acid liberated in the hydrolysate sample in relation to that in the control

231 sample (water).

233 The $\mathrm{IC}_{50}$ of hydrolysates was determined by making serial dilutions $(1 / 1,1 / 2.5,1 / 5$,

$2341 / 10,1 / 25$ and 1/50) of the hydrolysate and plotting the inverse of their ACEi\% versus

235 the inverse of their total protein concentration. The $\mathrm{IC}_{50}$ was determined from the

236 resulting linear equation and expressed as $\mu \mathrm{g} / \mathrm{mL}$.

\subsubsection{Sensory evaluation}

The sensory evaluation of the products was reviewed and approved by the University of Reading Ethics Committee. All participants gave written informed consent prior to taking part in the study. Sensory discrimination tests were carried out for the two different whey protein hydrolysates: (i) hydrolysate from CDP, and (ii) hydrolysate

243 from $\beta$-lactoglobulin. Prior to the sensory testing, the $\mathrm{IC}_{50}$ values of both hydrolysates 244 were measured as $145 \mu \mathrm{g} / \mathrm{mL}$ for $\beta$-lactoglobulin derived hydrolysate and $288 \mu \mathrm{g} / \mathrm{mL}$ 245 for CDP derived hydrolysate. The hydrolysates were spray dried and incorporated into 246 pasteurised semi skimmed milk based at three different concentrations related to their

$247 \mathrm{IC}_{50}: 100,150$ and $200 \mu \mathrm{g} / \mathrm{mL}$ for the $\beta$-lactoglobulin derived hydrolysate and 200 , 248300 and $400 \mu \mathrm{g} / \mathrm{mL}$ for the CDP derived hydrolysate. Samples were then stored at $2494{ }^{\circ} \mathrm{C}$ for $24 \mathrm{~h}$. Volunteers $(\mathrm{n}=39$, untrained, age 18-60) were recruited from the 250 students and staff of the University of Reading. The sensory tests were carried out in 251 individual sensory booths under artificial daylight conditions. Samples $(10 \mathrm{~mL})$ were 252 coded with three-digit random number and held in plastic cups $(30 \mathrm{~mL})$. The 253 discrimination test followed a forced choice triangle test methodology, each panellist 
receiving a triad of either two samples and a control (milk without hydrolysate) or vice versa, sample presentation orders were balanced. Panellists were asked to move

256 the sample around the mouth and then expectorate. They were asked to select the 257 sample that was different out of the three and to describe the difference(s) perceived. 258 Water and crackers were used for palate cleansing in between the samples.

\subsubsection{Stability study}

\subsubsection{Gastrointestinal digestibility study}

The in-vitro stability of hydrolysates was studied by simulating the gastrointestinal

264 environment and subjecting them to the action of pepsin at $\mathrm{pH} 2$ and $\mathrm{E}: \mathrm{S}$ ratio of 1:

26550 , temperature $37{ }^{\circ} \mathrm{C}$ for $90 \mathrm{~min}$ as previously described by Ortiz-Chao (2008). After 266 this incubation, the hydrolysate was adjusted to $\mathrm{pH} 7$ and the hydrolysis was started 267 by adding corolase PP at E/S ratio of 1:25 for 150 min in a water bath with shaking. 268 The reaction mixture was stopped by heating at $95{ }^{\circ} \mathrm{C}$ for $15 \mathrm{~min}$ and then centrifuged 269 for half an hour at $15000 \mathrm{x}$ g. Finally the supernatant was stored in the freezer at $270-20{ }^{\circ} \mathrm{C}$ until further analysis.

\subsubsection{In-silico digestibility study}

274 In silico digestion of the peptides identified in this work was performed using a 275 combination of pepsin, trypsin and $\alpha$-chymotrypsin to simulate in-vitro human 276 gastrointestinal digestion with the software PeptideCutter proteomics tool 277 (http://www.expasy.org). The preferred hydrolysis sites of these three gastrointestinal 
279 leucine for pepsin; C-terminus of arginine and lysine for trypsin; and C-terminus of 280 tryptophan, tyrosine, phenylalanine, leucine, methionine and histidine for $\alpha$ 281 chymotrypsin.

2.2.7.3. Prediction of ACE inhibitory activity of main peptides in hydrolysates and their in silico digests

The ACE inhibitory activity of main peptides identified in the hydrolysate fractions was predicted using BIOPEP software (http://www.uwm.edu.pl/biochemia/index_en.php) and also published works.

289 Furthermore using the same software the ACE inhibitory activity of the in-silico

290 digested peptide fragments was predicted

\subsubsection{Total protein analysis}

293 The total protein content of hydrolysates was determined based on the bicinchoninic 294 acid (BCA) assay. In brief, two $\mathrm{ml}$ of the BCA working reagent (copper sulphate 295 solution: BCA solution at a ratio of 1:50) were mixed with $100 \mu$ l of sample. The 296 mixture was incubated for $30 \mathrm{~min}$ at $37{ }^{\circ} \mathrm{C}$ and the absorbance reading was taken at $297562 \mathrm{~nm}$ using ultrospec 1100 pro UV/ visible spectrophotometer. Serial dilutions of 298 bovine serum albumin were used as standard. 


\subsubsection{Statistical analysis}

302 The analysis of variance for the results of the above experiments was computed using

303 Genstat statistical software package for statistical comparison among groups of 304 different treatments, with $\mathrm{P}<0.05$ indicating significant difference. All the above 305 results were expressed as Mean \pm standard error of mean (S.E.M). Data from the 306 sensory analysis was analyzed using the binomial probability model at a significant 307 level of 0.05 (Difftest version 2.0, 2002, www.difftest.co.uk).

\section{Results and discussion}

Mass spectrometry analysis of peptide compositions in sweet whey confirmed the

313 presence of ten peptides ranging from 1881.1 to 20978.7 Da (see Figure 2). Several

314 studies also indicated the presence of CDP in whey during cheese manufacturing as a 315 result of proteolysis of casein proteins by chymosin and endogenous milk enzymes 316 (Fox, 1993). Particularly, plasmin activity could be high at conditions of rennet whey 317 preparation $\left(35 \pm 2{ }^{\circ} \mathrm{C}\right.$ and $\mathrm{pH}$ of milk) (Bastian and Brown, 1996).

In our previous works (Welderufael and Jauregi, 2010 and Welderufael et al 2012) we demonstrated that applying the integrative approach to whey resulted in the production of two different hydrolysates, one from CDP and the other one from $\beta$ lactoglobulin. In the present work we carried out the chemical characterisation of each 324 hydrolysate using mass spectrometer techniques in order to identify the main peptides contributing to the ACE inhibitory activity measured in these hydrolysates. 


\subsection{Identification and characterisation of major peptide composition derived from}

active fractions of CDP

The structure-function relationship of ACE inhibitory peptides is not fully characterised however some information exists and quantitative structure activity relationships (QSAR) have been established (Pripp, Isaksson, Stepaniak, Sørhaug,\& Ardö, 2005 and Wu, Aluko, \& Nakai, 2006) which, enable prediction of ACE inhibitory activity from a knowledge of amino acid sequences. ACE cleaves dipeptides from the C-terminal sequences of peptide substrates and particularly the three amino acids from the C-terminal are very important for their binding to ACE (LopezFandino et al., 2006). Furthermore, this enzyme prefers small peptides up to 12 amino acids in length with hydrophobic amino acids (aromatic: phenylalanine, tryptophan and tyrosine; and branched chain amino acids: valine, leucine and isoleucine) in one of the three sequences of the C-terminal (Cheung et al., 1080; Mullally et al., 1997b). The positively charged amino acids such as arginine and lysine at the C-terminal sequences were also reported to contribute towards ACE inhibitory or antihypertensive effect (Cheung et al., 1980).

The mass spectrometry analysis of the 2 and $6 \mathrm{~h}$ hydrolysates which had permeated through the $1 \mathrm{kDa}$ ultrafiltration membrane show that both hydrolysates contain almost the same peptide composition with peptides mainly from casein derived peptides (see Table 2 for peptide compositon of the $2 \mathrm{~h}$ hydrolysate).

These two hydrolysates were fractionated into 8 fractions (see $2 \mathrm{~h}$ hydrolysate chromatogram in Fig 3 ) and the three polar fractions A, B and C showed the highest bioactivity. Particularly, fraction "B" in both, the 2 (see Table 2 and Figure 4) and $6 \mathrm{~h}$ 
353 hydrolysates (data not shown) contained IPP. This peptide has been identified as the 354 most potent ACE inhibitor from milk protein and it is derived from casein with an $355 \mathrm{IC}_{50}$ of $5 \mu \mathrm{M}(1.6 \mu \mathrm{g} / \mathrm{mL})$ (Nakamura et al., 1995). In recent years, several human 356 trials and animal studies have demonstrated the antihypertensive activity of this 357 tripeptide (Ehlers, Nurmi, Turpeinen, Korpela, \& Vapaatalo, 2011). In addition, this 358 fraction, in both hydrolysates, contained the peptide His-Leu-Pro (HLP) which could 359 be a contributor to ACE inhibitory activity as it is a fragment of the $\beta$-casein derived 360 hexapeptide Leu-His-Leu-Pro-Leu-Pro (LHLPLP). This hexapeptide has been 361 reported to have an $\mathrm{IC}_{50}=5.5 \pm 0.5 \mu \mathrm{M}=3.8 \mu \mathrm{g} / \mathrm{mL}$ and has also shown a significant 362 blood pressure reduction effect at a dosage of $2 \mathrm{mg} / \mathrm{kg}$ (Quiros et al., 2009).

364 Fraction "C" of the $2 \mathrm{~h}$ hydrolysate contained a $\beta$-lactoglobulin derived peptide Leu365 Asp-Ile-Gln-Lys (LDIQK) while it was absent in the $6 \mathrm{~h}$ one. This pentapeptide is a 366 fraction of the ACE inhibitory hexapeptide Gly-Leu-Asp-Ile-Gln-Lys (GLDIQK) 367 which has been reported as a potent $\mathrm{ACE}$ inhibitor with an $\mathrm{IC}_{50}$ of $27.5 \mu \mathrm{M}$ or 18.5 $368 \mu \mathrm{g} / \mathrm{mL}$ (Schlothauer, Schollum, Singh \& Reid, 1999). This same fraction, in both 369 hydrolysates, also contained an octapeptide Gln-Asp-Lys-Thr-Glu-Ile-Pro-Thr 370 (QDKTEIPT). In order to identify the main peptides responsible for the high 371 bioactivity of fraction $\mathrm{C}$, the fraction of the $6 \mathrm{~h}$ hydrolysate was further fractionated 372 into four sub-fractions. This led to a fraction containing almost solely the octapeptide 373 QDKTEIPT and its $\mathrm{IC}_{50}$ was $17.5 \mu \mathrm{g} / \mathrm{mL}$ (see Figure 5 and 6). So this proves that the 374 octapeptide was one of the main contributors to the $\mathrm{IC}_{50}$ measured in fraction $\mathrm{C}$ (113 $375 \mu \mathrm{g} / \mathrm{ml}$ ). Furthermore this peptide holds some structural similarities to other reported 376 ACE inhibitory peptides. Quirós et al. (2005) reported an ACE inhibitory peptide 377 Leu-Val-Tyr-Pro-Phe-Thr-Gly-Pro-Ile-Pro-Asn (LVYPFTGP $\underline{I P N}$ ) from caprine kefir 
with an $\mathrm{IC}_{50}$ of $27.9 \pm 2.3 \mu \mathrm{g} / \mathrm{mL}$. This peptide has the same two penultimate sequences Iso-leucine and Proline at the end of the C-terminal as the octapeptide (QDKTEIPT). Moreover both peptides have uncharged and polar amino acids such as, asparagine and threonine at the $\mathrm{C}$-terminal end. Therefore, taking into account all the above evidence both peptides LDIQK and QDKTEIPT are most likely to be the main contributors to the high potency of fraction " $\mathrm{C}$ " of the $2 \mathrm{~h}$ hydrolysate. The octapeptide QDKTEIPT is the main contributor to the potency of the $6 \mathrm{~h}$ hydrolysate.

The $\beta$-lactoglobulin derived tetrapeptide Lys-Ile-Pro-Ala (KIPA) in fraction "B" has a very similar peptide sequence to a tripeptide reported by Abubakar and co-authors (1998), the Ile-Pro-Ala (IPA), which was found to be a potent ACE inhibitor with $\mathrm{IC}_{50}=141 \mu \mathrm{M}(42 \mu \mathrm{g} / \mathrm{mL})$.

Fraction "A" also showed a high ACEi activity. Six peptide sequences Leu-Arg, MetAla-Pro-Lys, Ala- Met-Ala-Pro-Lys, Ile/Leu-Gln-Lys, Val-Ser-Lys and Thr-Val-Lys were among the peptides identified in this fraction (see Figure 7). These peptides, like the other well characterised ACE inhibitory peptides, also had some structural features of ACE-inhibitors, e.g: the presence of charged followed by hydrophobic amino acid residues in one of the penultimate sequences at the $\mathrm{C}$-terminal sequences. Interestingly, the tripeptide Thr-Val-Lys found in this fraction contained the same Cterminal sequence as the ACE inhibitory peptide Val-Lys extracted from buckwheat with an $\mathrm{IC}_{50}$ value of $13 \mu \mathrm{M}=3.17 \mu \mathrm{g} / \mathrm{mL}$ (Vermeirssen, Bent, Camp, Amerongen \& Verstraete, 2004). 


\subsection{Identification and characterization of major peptides in the hydrolysate}

containing peptides derived from $\beta$-lactoglobulin

Selective hydrolysis of the immobilised $\beta$-lactoglobulin after removing the $2 \mathrm{~h}$ hydrolysates of casein derived peptides by adding two different concentrations of fresh enzyme at an E:S ratio of 1:100 and 1:50 resulted in a hydrolysate with a composition different to that obtained at $2 \mathrm{~h}$, with peptides mainly from $\beta$ lactoglobulin and with increased bioactivity. Even if the peptide composition of these two $\beta$-lactoglobulin derived hydrolysates was similar, the relative abundance of individual peptides was different (see Figure $8 \mathrm{a}$ and $\mathrm{b}$ ). Almost all these major peptides contained either charged or hydrophobic amino acids in one of the three Cterminal sequences (see Table 3).

Interestingly, the relative abundance of the tetrapeptide Ile-Ile-Ala-Glu (IIAE) increased with an increase in an E: S ratio from 1:100 to 1:50. This peptide was one of the two most abundant peptides in the hydrolysate of the 1:50 E:S ratio and shared similarities with a potent microalgae derived tripeptide Ile-Ala-Glu (IAE). This tripeptide was reported to have an $\mathrm{IC}_{50}=34.7 \mu \mathrm{M}=11.5 \mu \mathrm{g} / \mathrm{mL}$ (Suetsuna \& Chen, 2001). The other major peptide was Lys-Pro-Thr-Pro-Glu-Gly-Asp-Leu-Glu-Ile-LeuLeu (KPTPEGDLEILL) and it increased with an increase in E:S ratio (see Figure 8a and $8 b$ ) which resulted in an increase in ACE inhibitory activity. This peptide contained three hydrophobic amino acids at the end of the C-terminal sequence. Therefore these two peptides IIAE and KPTPEGDLEILL could be the major contributors for the high ACE inhibitory activity measured in this hydrolysate. Furthermore the two amino acids at the N-terminal sequence of $\underline{K P T P E G D L E I L L}$ 
were similar to the dipeptide Lys-Pro (KP) that was isolated from anchovy and bonito.

This dipeptide is known for its high ACE inhibitory activity, $\mathrm{IC}_{50}=22 \mu \mathrm{M}=$ $5.3 \mu \mathrm{g} / \mathrm{mL}$ and an animal study showed a significant blood pressure reduction effect

431 (Toshiaki, Jianen, Duong \& Susumu, 2003). A tripeptide Val-Phe-Lys (VFK) was 432 also identified in this hydrolysate and it has been reported to have ACE inhibitory 433 activity with $\mathrm{IC}_{50}=1029 \mu \mathrm{M}=402.6 \mu \mathrm{g} / \mathrm{mL}$ (Pihlanto-Leppala et al., 2000). in the hydrolysate of a standard $\beta$-lactoglobulin solution (not immobilized) obtained at the same experimental conditions in previously carried out work by our group (Ortiz-Chao et al., 2009). Out of these eight peptides, all except LIVTQ were identified in the mixtures of the most active fractions. Therefore the hydrolysis process shows good reproducibility. An additional novel peptide KPTPEGDLEILL was identified in the current work that could be a potential contributor to ACE inhibitory activity. Besides these interesting findings, the most interesting outcome of this work is that unlike the complex peptide mixture produced from the standard $\beta$ lactoglobulin solution, the hydrolysates produced here were less complex and with comparable $\mathrm{IC}_{50}$ values $\left(\mathrm{IC}_{50}=128 \mu \mathrm{g} / \mathrm{mL}\right.$ for the immobilized whey whereas 102 $\mu \mathrm{g} / \mathrm{mL}$ for the standard $\beta$-lactoglobulin solution).

\subsection{Impact of simulated gastrointestinal digestion on ACE inhibitory activity} inhibitory activity after oral administration due to further hydrolysis by

452 gastrointestinal enzymes (Walsh et al., 2004). In this work, the ACE inhibitory 453 activity of CDP and $\beta$-lactoglobulin derived hydrolysates was further assessed after 
the in-vitro simulated gastrointestinal digestion. The results showed no significant differences in ACE inhibitory activity before and after the in-vitro digestion (see Figure 9). This could be because either the potent peptides that contributed to the inhibitory activity might be resistant to digestion or the digestion resulted in partial hydrolysis and the active sequences were maintained intact with little impact on the bioactivity. This was tested further by carrying out in-silico digestion of major peptides in most active fractions.

\subsection{In-silico digestibility study of CDP derived peptides}

466 silico digestion of individual peptides was carried out following the method in section

2.2.7.2. Furthermore the ACE inhibitory activity of the peptides produced after

digestion was predicted following method in 2.2.7.3. Out of 25 peptide sequences reported in the $2 \mathrm{~h}$ hydrolysate, 9 of the peptides were found to be resistant to digestive enzymes including the most potent ACE inhibitory tripeptide IPP while only 4 were completely digested. Twelve peptides were partially hydrolysed (see Table 4) but their C-terminal sequences remained intact. Furthermore, out of the ten peptides that were mainly derived from $\beta$-lactoglobulin, only two were completely digested, three were resistant to gastrointestinal digestion while five of the peptides were

475 partially hydrolysed. The three peptides resistant to the digestive enzymes were: Ile476 Ile-Ala-Glu, Ile-Val-Thr-Gln and Val-Ala-Gln-Thr (see Table 3).

478 The octa-peptide Gln-Asp-Lys-Thr-Glu-Ile-Pro-Thr that was predominant in the 479 active fraction "Fraction C" (Table 2 and table 4) was digested into two peptides Gln480 Asp-Lys and Thr-Glu-Ile-Pro-Thr. These two digests have some structural features of 
481 ACE inhibitors. Both peptides contained charged or hydrophobic amino acids at the 482 two penultimate sequences at the end of the C-terminal.

484 A peptide Leu-Thr-Gln-Thr-Pro-Val (LTQTPV) was predicted to loose L-leucine 485 from the N-terminal sequence and produce TQTPV. This peptide shared similarities at 486 the C-terminal sequence with an ACE inhibitory peptide Asn-Ile-Pro-Pro-Leu-Thr487 Gln-Thr-Pro-Val produced from fermented milk by Lactobacillus delbrueckii 488 subspecies bulgaricus SS1 and Lactobacillus lactis subspecies cremoris FT4 with an $489 \mathrm{IC}_{50}$ of $173 \mu \mathrm{M}$ (Gobbetti, Ferranti, Smacchi, Goffredi \& Addeo, 2000).

491 The octapeptide derived from caseinomacropeptide Met-Ala-Ile-Pro-Pro-Lys-Lys-Asn 492 (MAIPPKKN) was predicted to loose the amino acid asparagine from the C-terminal 493 sequence resulting in MAIPPKK which is known for its vasodilatory effect. This 494 peptide is a modest $\mathrm{ACE}$ inhibitor with $\mathrm{IC}_{50}$ of $4785 \mu \mathrm{M}$ however, in an animal study 495 this peptide showed a significant blood pressure reduction effect at a dose level of 496 10mg/kg (Miguel, Manso, López-fandiño, Alonso \& Salaices, 2007). 
498 The peptide Ile-Ile-Ala-Glu-Lys-Thr (IIAEKT) was susceptible to partial digestion 499 and was predicted to loose threonine from the end of the Carboxyl-terminal. This

500 fragment, IIAEK (lactostatin) was reported to exhibit a greater hypercholesterolemia

501 effect even when compared to the drug $\beta$-sitosterol as tested in rats (Nagaoka et al., 502 2001).

503

504 Interestingly the findings from the in-vitro and in-silico digestibility studies were in 505 agreement as using both methods it was found that digestion of the hydrolysates 506 resulted in no loss of ACE inhibitory activity.

\section{$507 \quad 3.5$. Sensory evaluation}

508 Sensory is one of the most important aspects that need to be given consideration after 509 the production of hydrolysates. The release of bitter tasting peptides can significantly 510 affect the sensory attributes of the resultant hydrolysate and subsequently alter the 511 quality of products to which they are added. Therefore to assess whether the 512 hydrolysate products developed in this study had any effect on a typical beverage, 513 they were added into milk which was subjected to a sensory discrimination test. Milk 514 with hydrolysate addition was compared to a control milk sample with no addition. 
523 Overall, for the CDP and $\beta$-lactoglobulin derived hydrolysates no significant

524 differences were found in perception between any of the three samples and the control 525 milk samples (see tables 5 and 6). However the sample with the lowest level of 526 hydrolysate was the most different to the control milk ( $\mathrm{p}=0.066)$. With the relatively 527 low number of assessors $(n=39)$ used in the trials, although there was no significant 528 differences in perception found, the samples could not be declared with confidence to 529 be perceptually identical, as either the proportion of discriminators amongst the 530 population was too high $(>30 \%)$, or at a risk level of $10 \%$ (type II error) the 531 probability of correctly identifying a sample from the control in any individual trial 532 was too high (the upper bound limit), or the probability of obtaining a result higher 533 than the upper bound limit was too high. The results of this pilot study must be scaled 534 up and taken to a larger consumer trial in order to prove the samples with hydrolysate 535 are perceptually identical to milk.

536 CDP derived hydrolysates: Three different concentrations of hydrolysate derived 537 from CDP were tested for sensory attributes. The $\mathrm{IC}_{50}$ of CDP derived hydrolysate 538 was $288 \mu \mathrm{g} / \mathrm{mL}$. Therefore we used three different concentrations, (i) $200 \mu \mathrm{g} / \mathrm{mL}$ (ii) $539300 \mu \mathrm{g} / \mathrm{mLand}$ (ii) $400 \mu \mathrm{g} / \mathrm{mL}$.

540 Although there was no statistical significant difference between the control and the 541 three different hydrolysate concentrations (see Table 5), comments given by the 542 assessors were compiled. The $200 \mu \mathrm{g} / \mathrm{mL}$ and the $300 \mu \mathrm{g} / \mathrm{mL}$ were described as less 543 sweet compared to the control, by 4 and 3 assessors respectively, and 3 assessors 544 described the taste and odour of the $400 \mu \mathrm{g} / \mathrm{mL}$ as less milky. However, there were no 545 comments concerning off notes, taints or bitter taste. These findings are very 546 interesting as they help to demonstrate the advantage of the integrative process in 
547 thatthe hydrolysates produced here are enriched in specific peptides and partially

548 fractionated which might have resulted in the removal of bitter fractions. Other

549 authors have used ion exchange as a debittering method (Cheison, Wang \& $\mathrm{Xu}$,

550 2007). Bitterness of hydrolysates is mainly caused by the composition of amino acids

551 in the peptide sequence. Smaller peptides less than $3 \mathrm{kDa}$ and hydrophobic amino

552 acids in the order of phenylalanine $(\mathrm{F}) \approx \operatorname{tryptophan}(\mathrm{W})>$ Proline $(\mathrm{P})>$ isoleucine $(\mathrm{I})$

$553 \approx$ tyrosine $(\mathrm{Y}) \approx$ histidine $(\mathrm{H})$ are reported to be the main contributors to bitterness

554 (Cheung et al., 2010; Linde, Junior, Faria, Colauto, Moraes \& Zanin, 2009). In our

555 hydrolysate, we have identified twenty five peptides from the active fractions that

556 were permeated through the $1 \mathrm{kDa}$ ultrafiltration membrane. Out of the twenty five

557 major peptides, only four peptides VSK, TVK, VQVT and TVQVT were free from

558 the above mentioned bitterness causing amino acids. The other twenty one peptides

559 contain at least one of these amino acids. However even if the majority of these

560 peptides contained Phe, Tyr, Trp, Pro, Ile or His amino acids, their position in the

561 peptide sequence plays a major role in the development of bitterness as reported by

562 Otagiri et al. (1985). Otagiri and co-authors reported the above mentioned amino

563 acids should be at the end of the C-terminal sequences. However, within our

564 hydrolysate only four peptides PP, IPP, HLP and LTQTP have this structural feature

565 while the rest contain those amino acids either at the $\mathrm{N}$-terminus or within the peptide

566 sequence. Furthermore, they found that peptides with arginine followed by proline

567 had a strong bitter taste.

$569 \quad \beta$-lactoglobulin derived hydrolysate: Three different concentrations were also tested

570 for the $\beta$-lactoglobulin derived hydrolysate. The $\mathrm{IC}_{50}$ of this hydrolysate was 145

$571 \mu \mathrm{g} / \mathrm{mL}$. Therefore three different concentrations were chosen in relation to its $\mathrm{IC}_{50}$; (i) 

significant difference between the three different concentrations and the control (see Table 6). From the compiled comments, only 2 assessors out of 39 reported adverse tastes; one reported sour for the $100 \mu \mathrm{g} / \mathrm{mL}$ sample and the other reported bitter for the $150 \mu \mathrm{g} / \mathrm{mL}$. Moreover, only 4 assessors described the $300 \mu \mathrm{g} / \mathrm{mL}$ samples as less sweet compared to the control.

A total of ten major peptides were identified in this hydrolysate and out of the ten peptides, only three peptides VAGT, RL and LDAQ were free from the above bitterness causing amino acids. The other seven peptides FK, IIAE, IVTQ, KPTPEGDLEILL, LIVT, LIVTQ and VFK contain at least one of these bitterness causing amino acids $(\mathrm{F} \approx \mathrm{W}>\mathrm{P}>\mathrm{I} \approx \mathrm{Y} \approx \mathrm{H})$. All the identified peptides did not contain these amino acids at their ultimate C-terminal position. However only three peptides FK, IIAE and IVTQ contain phenylalanine and isoleucine at the ultimate Nterminus and four peptides KPTPEGDLEILL, LIVT, LIVTQ and VFK contained proline, isoleucine or phenylalanine within their sequences. Therefore, the majority of the peptides identified in the hydrolysate according to their chemical structure were expected not to be bitter which is in agreement with the results of the sensory analysis.

\section{Conclusions}

This study demonstrated that the production process applied in this work resulted in hydrolysates of high ACE inhibitory activity. The fractionation of hydrolysates by preparative HPLC and the use of MS techniques helped to identify major bioactive peptides. This together with available structure activity relationship data including QSAR enable identification of main peptides contributing to the ACE inhibitory 
598 activity of hydrolysates. Among these potent peptides some novel sequences were 599 identified such as, VSK, IIAE, QDKTEIPT, KPTPEGDLEILL and LDIQK . Also the

600 well known ACE inhibitory peptide IPP was identified in the CDP derived

601 hydrolysates. The in-vitro simulated gastrointestinal digestibility study showed that

602 there was no significant change in the ACE inhibitory activity of the hydrolysates

603 This was also in agreement with the findings from the in-silico digestion study. The 604 in-silico digestion of both hydrolysates predicted that most of the peptides were either

605 resistant or only susceptible to partial hydrolysis and the resulting fragments were

606 predicted to be ACE inhibitory. Hence, no overall loss of ACE inhibitory activity was

607 predicted. The sensory evaluation of the hydrolysates showed no significant

608 difference between the reconstituted hydrolysate products and the control. This might

609 be due to low structural similarity of the peptides with that of bitterness causing

610 peptides. Overall this work demonstrates the advantage of producing hydrolysates

611 following the integrative approach as less complex hydrolysates with high potency

612 and with positive sensory attributes can be produced.

613

614 Acknowledgements

615 We would like to thank Kerry Group and BBSRC for funding this research. 
618 Abubakar, A., Saito, T., Kitazawa, H., Kawai, Y., \& Itoh, T. (1998). Structural

619 Analysis of New Antihypertensive Peptides Derived from Cheese Whey Protein by

620 Proteinase K Digestion. Journal of Dairy Science, 81, 3131-3138.

Bastian ED, Brown RJ. 1996. Plasmin in Milk and dairy Products: an Update: Review article. International Dairy Journal, 6:435-457.

Ceconi, C., Francolini, G., Olivares, A., Comini, L., Bachetti, T., \& Ferrari, R. (2007). Angiotensin-converting enzyme (ACE) inhibitors have different selectivity for bradykinin binding sites of human somatic ACE. European Journal of Pharmacology, 577, 1-6.

Cheison, S. C., Wang, Z., \& Xu, S.Y. (2007). Use of macroporous adsorption resin for simultaneous desalting and debittering of whey protein hydrolysates. International Journal of Food Science and Technology, 42, 1228-1239.

Cheung, H.-S., Wang, F.-L., Ondetti, M., Sabo, E., \& Cushman, D. (1980). Binding of Peptide Substrates and Inhibitors of Angiotensin-converting Enzyme: Importance of the $\mathrm{COOH}$ - terminal dipeptide sequences. The Journal of Biological Chemistry, 255, 401-407.

Cheung, I. W. Y., \& Li-Chan, E. C. Y. (2010). Angiotensin-I-converting enzyme inhibitory activity and bitterness of enzymatically-produced hydrolysates of shrimp (Pandalopsis dispar) processing by products investigated by Taguchi design. Food Chemistry, 122, 1003-1012.

Coppey, L. J., Davidson, E. P., Rinehart, T. W., Gellett, J. S., Oltman, C. L., Lund, D. D., \& Yorek, M. A. (2006). ACE inhibitor or angiotensin II receptor antagonist attenuates diabetic neuropathy in streptozotocin-induced diabetic rats. Diabetes, 55, 341-348.

Ehlers PI, Nurmi L, Turpeinen AM, Korpela R \& Vapaatalo H. (2011). Caseinderived tripeptide Ile-Pro-Pro improves angiotensin-(1-7)- and bradykinin-induced rat mesenteric artery relaxation. Life Sciences, 88, 206-211.

Ferreira, S. H. (1965). A bradykinin-potentiating factor (BPF) present in the venom of Bothrops jararaca. British Journal of Pharmacology and Chemotherapy, 24, 163-169.

Fox, P. (1993) Studies on Dairy Chemistry: Chemistry and Biochemistry of Cheese. PhD Thesis, Cork, University College Cork.

Gobbetti, M., Ferranti, P., Smacchi, E., Goffredi, F., \& Addeo, F. (2000). Production of angiotensin-I-converting enzyme inhibitoy peptides in fermented milks started by Lactobacillus delbrueckii subsp. bulgaricus SS1 and Lactococcus lactis subsp. cremoris FT4. Applied and Environmental Microbiology, 66, 3898-3904. 
Hernandez-Ledesma, B., Recio, I., Ramos, M., \& Amigo, L. (2002). Preparation of ovine and caprine $\beta$-lactoglobulin hydrolysates with ACE-inhibitory activity. Identification of active peptides from caprine $\beta$-lactoglobulin hydrolysed with thermolysin. International Dairy Journal, 12, 805-812.

Hyun, C. K., \& Shin, H. K. (2000). Utilization of bovine blood plasma proteins for the production of angiotensin I converting enzyme inhibitory peptide. Process Biochemistry, 36, 65-71.

Jauregi, P. (2008). Bioactive peptides from food proteins: New opportunities and challenges: a review. Food Science and Technology/Bulletin, 5, 11-25.

Jauregi, P., \& Welderufael, F. T. (2010). Added-value protein products from whey. NUTRAfoods, 9, 13-23.

Je, J.-Y., Park, P.-J., Byun, H.-G., Jung, W.-K., \& Kim, S.-K. (2005). Angiotensin I converting enzyme (ACE) inhibitory peptide derived from the sauce of fermented blue mussel, Mytilus edulis. Bioresource Technology, 96, 1624-1629.

Kilara, A., \& Panyam, D. (2003). Peptides from milk proteins and their properties. Critical Reviews in Food Science and Nutrition, 43, 607-633.

Korhonen, H., \& Pihlanto, A. (2006). Bioactive peptides: production and functionality. International Dairy Journal, 16, 945-960.

Linde, G. A., Junior, A. L., Faria, E. V. d., Colauto, N. B., Moraes, F. F. d., \& Zanin, G. M. (2009). Taste modification of amino acids and protein hydrolysate by $\alpha-$ Cyclodextrin. Food Research International, 42, 814-818.

Lopez-Fandino, R., Otte, J., \& van Camp, J. (2006). Physiological, chemical and technological aspects of milk-protein-derived peptides with antihypertensive and ACE-inhibitory activity. International Dairy Journal, 16, 1277-1293.

Mehanna, A. S., \& Dowling, M. (1999). Liquid chromatographic determination of hippuric acid for the evaluation of ethacrynic acid as angiotensin converting enzyme inhibitor. Journal of Pharmaceutical and Biomedical Analysis, 19, 967-973.

Miguel, M., Manso, M. A., Lopez-Fandino, R., Alonso, M. J., \& Salaices, M. (2007). Vascular effects and antihypertensive properties of $\kappa$-casein macropeptide. International Dairy Journal, 17, 1473-1477.

Mullally, M. M., Meisel, H., \& FitzGerald, R. J. (1997a). Angiotensin-I-converting enzyme inhibitory activities of gastric and pancreatic Proteinase digests of whey proteins. International Dairy Journal, 7, 299-303.

Mullally, M. M., Meisel, H., \& FitzGerald, R. J. (1997b). Identification of a novel angiotensin-I-converting enzyme inhibitory peptide corresponding to a tryptic 
Nagaoka, S., Futamura, Y., Miwa, K., Awano, T., Yamauchi, K., Kanamaru, Y.,

714 Tadashi, K ., Kuwata, T., (2001). Identification of novel hypocholesterolemic peptides communications, 281, 11-17.

Nakamura, Y., Yamamoto, N., Sakai, K., Okubo, A., Yamazaki, S., \& Takano, T. (1995). Purification and characterisation of angiotensin I-converting enzyme inhibitors from sour milk. Journal of Dairy Science, 78, 777-783.

Ortiz-Chao, P. (2008). $\beta$-lactoglobulin derived bioactive peptides: A study of the feasibility of an ion exchange process for their production. Food Biosciences, $P h D$ Thesis. Reading: Reading University.

Ortiz-Chao, P., Gomez-Ruiza, J. A., Rastalla, R. A., Millsb, D., Cramerb, R., Pihlantoc, A., Korhonenc, H., \& Jauregi, P. (2009). Production of novel ACE inhibitory peptides from $\beta$-lactoglobulin using Protease $\mathrm{N}$ 'Amano'. International Dairy Journal, 19, 69-76.

Otagiri, K., Nosho, Y., \& Shinoda, I. (1985). Studies on a Model of Bitter Peptides including Arginine, Proline and Phenylalanine Residues. I. Bitter Taste of Di- and Tripeptides, and Bitterness Increase of the Model Peptides by Extension of the Peptide Chain. Agricultural and Biological chemistry, 49, 1019-1102.

Otte, J., Shalaby, S. M., Zakora, M., Pripp, A. H., \& El-Shabrawy, S. A. (2007). Angiotensin-converting enzyme inhibitory activity of milk protein hydrolysates: Effect of substrate, enzyme and time of hydrolysis. International Dairy Journal, 17, 488-503

Pedroche, J., Yust, M. M., Lqari, H., Megias, C., Giron-Calle, J., Alaiz, M., Vioque, J., \& Millan, F. (2007). Obtaining of Brassica carinata protein hydrolysates enriched in bioactive peptides using immobilized digestive proteases. Food Research International, 40, 931-938.

Pihlanto-Leppala, A., Koskinen, P., Piilola, K., Tupasela, T., \& Korhonen, H. (2000). Angiotensin-I-converting enzyme inhibitory properties of whey protein digests. concentration and characterisation of active peptides. Journal of Dairy Research, 67, 53-64.

Pripp, A. H., Isaksson, T., Stepaniak, L., Sørhaug, T., \& Ardö, Y. (2005).

Quantitative structure activity relationship modelling of peptides and proteins as a tool in food science. Trends in Food Science and Technology, 16, 484-494

Quiros, A., Contreras, M. a. d. M., Ramos, M., Amigo, L., \& Recio, I. (2009). Stability to gastrointestinal enzymes and structure-activity relationship of $\beta$-casein peptides with antihypertensive properties. Peptides, 30, 1848-1853.

Quiros, A., Hernandez-Ledesma, B., Ramos, M., Amigo, L., \& Recio, I. (2005). Angiotensin-Converting Enzyme Inhibitory Activity of Peptides Derived from Caprine Kefir. Journal of Dairy Science, 88, 3480-3487. 
764 Quiros, A., Ramos, M., Muguerza, B., Delgado, M. A., Miguel, M., Aleixandre, A., \&

Recio, I. (2007). Identification of novel antihypertensive peptides in milk fermented with Enterococcus faecalis. International Dairy Journal, 17, 33-41.

Schlothauer, R.-C., Schollum, L., Singh, A., \& Reid, J. (1999). Bioactive whey protein hydrolysate. World Patent WO 99/65326.

Spellman, D., O'Cuinn, G., \& FitzGerald, R. J. (2005). Physicochemical and sensory characteristics of whey protein hydrolysates generated at different total solids levels. Journal of Dairy Research, 72, 138-143.

Suetsuna, K., \& Chen, J. R. (2001). Identification of antihypertensive peptides from peptic digests of two microalgae, Chlorella vulgaris and Spirulina platensis. Marine Biotechnology, 3, 305-309.

Toshiaki, I., Jianen, H., Duong, Q. A., \& Susumu, M. (2003). Angiotensin I Converting Enzyme Inhibitory Activity and Insulin Secretion Stimulative Activity of Fermented Fish Sauce. Journal of Biosciences and Bioengineering, 96, 496-499.

Vermeirssen, V., Bent, A. v. d., Camp, J. V., Amerongen, A. v., \& Verstraete, W. (2004). A quantitative in silico analysis calculates the angiotensin I converting enzyme (ACE) inhibitory activity in pea and whey protein digests. Biochimie, 86, 231-239.

Walsh, D. J., Bernard, H., Murray, B. A., MacDonald, J., Pentzien, A.-K., Wright, G. A., Wal, J.-M., Struthers, A. D., Meisel, H., \& R.J. FitzGerald1 (2004). In Vitro Generation and Stability of the Lactokinin $\beta$-Lactoglobulin Fragment (142-148). Journal of Dairy Science, 87, 3845-3857.

Welderufael, F., \& Jauregi, P. (2010). Development of an Integrative Process for the Production of Bioactive peptides from whey by proteolytic mixtures. Separation Science and Technology, 45, 2226-2234.

Welderufael, F. T., Gibson, T., \& Jauregi, P. (2011). Production of angiotensin converting enzyme inhibitory peptides from $\beta$-lactoglobulin and casein derived peptides: an integrative approach. Accepted for publication in Biotechnology Progress

Wu, J., Aluko, R. E., \& Nakai, S. (2006). Structural Requirements of Angiotensin I Converting Enzyme Inhibitory Peptides: Quantitative Structure - Activity Relationship Study of Di- and Tripeptides. Journal of Agricultural Food Chemistry, 54, 732-738. 


\section{FIGURE LEGENDS}

Figure 1: Flowchart of production of ACE inhibitory peptides from CDP and $\beta$ lactoglobulin $(\beta-\mathrm{Lg})$. Where P1 and P2 were the permeates of hydrolysates produced from CDP after 2 and 6 hours hydrolysis and P3 the hydrolysate from $\beta$-lactoglobulin after 2+6 h hydrolysis; P1 and P2 contained mainly CDP derived peptides and P3 $\beta$-lactoglobulin derived peptides.

Figure 2: Total ion current (TIC) of sweet whey extract with masses of peaks analysed by liquid chromatography coupled to mass spectrometry (LCMS).

Figure 3: Peptide peak profiles of the $2 \mathrm{~h}$ hydrolysate permeated through the $1 \mathrm{kDa}$ ultrafiltration membrane (P1) and peak profiles of the 8 fractions using semi-prep RPHPLC

Figure 4: (a) MS/MS spectrum of fraction "B" of the $2 \mathrm{~h}$ hydrolysate after filtration through the $1 \mathrm{kDa}$ ultrafiltration membrane (P1) (b) MS-MS spectrum of ion $\mathrm{m} / \mathrm{z}$ 326.2074 of IPP.

Figure 5: MS/MS spectrum of fraction "C" of the $2 \mathrm{~h}$ hydrolysate after filtration through the $1 \mathrm{kDa}$ ultrafiltration membrane $(\mathrm{P} 1)$.

Figure 6. MS/MS spectrum of subfraction from fraction" $C$ " of the 6 h hydrolysate (P2). The spectrum shows the ion $\mathrm{m} / \mathrm{z} 931.4827$ which corresponds to the doubly charged ion of the octapeptide QDKTEIPT (466.2418).

Figure 7: Micro-TOF/ESI-MS spectrometry of fraction "A" of the $2 \mathrm{~h}$ immobilised whey hydrolysate after filtration through the $1 \mathrm{kDa}$ ultrafiltration membrane (P1). 
838 Figure 8: Base peak chromatograms of hydrolysate with $\beta$-lactoglobulin derived

839 peptides (P3) at an enzyme to substrate (E:S) ratio of (a) 1:50 and (b) 1:100.

840

841

842

843 Figure 9: Percentage of ACE inhibitory activity of hydrolysates before and after the

844 in-vitro digestion using gastrointestinal digestive enzymes (pepsin, corolase PP).

845 Where 2+6 (E:S=1:100), 2+6 (E:S=1:50) and 2+6 (E:S=1:25) are hydrolysates

846 produced after filtering the $2 \mathrm{~h}$ hydrolysate (hydrolysate mainly from CDP) and

847 extending the hydrolysis of $\beta$-lactoglobulin for further 6 hours at an E:S ratio of 1:100,

$848 \quad 1: 50$ and 1:25.

849 


\section{TABLES}

\section{Table 1:}

Different ACE inhibitory hydrolysate production methods from whey proteins and from other natural sources and their $\mathrm{IC}_{50}$ values.

\begin{tabular}{|c|c|c|c|c|c|c|}
\hline Methods of production & Pro & ein source & $\begin{array}{l}\text { Hydrolysis } \\
\text { time (hrs) }\end{array}$ & Enrichment & $\begin{array}{l}\mathrm{IC}_{50} \\
(\mu \mathrm{g} / \mathrm{ml})\end{array}$ & Reference \\
\hline \multirow[t]{3}{*}{$\begin{array}{l}\text { TCA precipitation then } \\
\text { hydrolysis }\end{array}$} & $\checkmark$ & $\begin{array}{l}\text { Ovine } \beta \text {-lactoglobulin } \\
\text { from acid whey }\end{array}$ & 24 & Nil & $117-278$ & (Hernandez-Ledes \\
\hline & $\checkmark$ & $\begin{array}{l}\text { Ovine } \beta \text {-lactoglobulin } \\
\text { from sweet whey }\end{array}$ & 24 & Nil & $38-296$ & (Hernández-Ledesm \\
\hline & $\checkmark$ & $\begin{array}{l}\text { Caprine } \beta \text {-lactoglobulin } \\
\text { from sweet whey }\end{array}$ & 24 & Nil & $118-388$ & (Hernandez-Ledesm \\
\hline \multirow[t]{2}{*}{ Batch } & $\checkmark$ & WPC & 4 & Ultrafiltration $(1 \mathrm{kDa})$ & 201 & (Mullally, Meisel \& \\
\hline & $\checkmark$ & $\beta$-lactoglobulin & 4 & Ultrafiltration $(1 \mathrm{kDa})$ & 160 & (Mullally et al., 199 \\
\hline Batch & $\checkmark$ & CMP & 3 & Nil & 477 & (Otte, Shalaby, Zakc \\
\hline Fermentation & $\checkmark$ & Milk & $24-48$ & Nil & $420-520$ & (Pihlanto, Virtanen \\
\hline Immobilized enzyme & $\checkmark$ & Brassica carinata & - & Nil & 338 & (Pedroche et al., 200 \\
\hline Fermentation & $\checkmark$ & Blue mussels & 6 months & $\begin{array}{l}\text { Filtered, desalted } \\
\text { electrodialised then } \\
\text { lyophilized }\end{array}$ & 1010 & (Je, Park, Byun, Jun \\
\hline \multirow[t]{2}{*}{$\begin{array}{l}\text { Our work (Integrative } \\
\text { approach) }\end{array}$} & $\checkmark$ & $\mathrm{CDP}$ & 2 & $\begin{array}{l}\text { Nil } \\
\text { Ultrafiltration }(1 \mathrm{kDa})\end{array}$ & $\begin{array}{r}287 \\
67\end{array}$ & $\begin{array}{l}\text { (Welderufael et al., } \\
\text { (Welderufael \& Jaur }\end{array}$ \\
\hline & $\checkmark$ & $\beta$-lactoglobulin & 8 & Nil & 128 & (Welderufael et al., \\
\hline
\end{tabular}




\section{Table 2}

$\mathrm{IC}_{50}(\mu \mathrm{g} / \mathrm{mL})$ value and the major peptides of the three active fractions of the $2 \mathrm{~h}$

hydrolysate that were permeated through the $1 \mathrm{kDa}$ ultrafiltration membrane followed by fractionation using semi-prep RP-HPLC.

\begin{tabular}{|c|c|c|c|c|}
\hline Fraction & Peptides & $\begin{array}{l}\text { Protein } \\
\text { Source }\end{array}$ & $\begin{array}{r}\text { Observed } \\
\text { Masses (Da) }\end{array}$ & $\begin{array}{r}\mathrm{IC}_{50} \\
(\mu \mathrm{g} / \mathrm{mL})\end{array}$ \\
\hline \multirow[t]{10}{*}{ A } & $\mathrm{PE}$ & & 245.1057 & 213 \\
\hline & $\mathrm{L} / \mathrm{IK}$ & $\beta-\mathrm{Lg}$ & 260.1928 & \\
\hline & $\mathrm{L} / \mathrm{IR}$ & $\beta-\operatorname{Lg}$ & 288.3398 & \\
\hline & VSK & $\beta$-casein & 333.3596 & \\
\hline & TVK & Casein kinase & 347.3637 & \\
\hline & PHL & k-casein & 365.2534 & \\
\hline & $\mathrm{I} / \mathrm{LQK}$ & $\beta-\mathrm{Lg}$ & 388.2582 & \\
\hline & MAPK & $\beta$-casein & 446.5118 & \\
\hline & LQPE & $\beta$-casein & 486.2502 & \\
\hline & AMAPK & $\beta$-casein & 517.4536 & \\
\hline \multirow[t]{11}{*}{ B } & PP & $\mathrm{k}$-casein & 213.3244 & 62 \\
\hline & IPP & k-casein & 326.2074 & \\
\hline & HLP & $\beta$-casein & 366.3774 & \\
\hline & VFK & $\beta-\operatorname{Lg}$ & 393.5045 & \\
\hline & KIPA & $\beta-\mathrm{Lg}$ & 428.5043 & \\
\hline & VQVT & k-casein & 446.2622 & \\
\hline & LQPE & $\beta$-casein & 486.2572 & \\
\hline & TVQVT & k-casein & 547.3091 & \\
\hline & LTQTP & $\beta$-casein & 559.3091 & \\
\hline & IASGEPT & k-casein & 674.7145 & \\
\hline & MAIPPKKN & $\mathrm{k}$-casein & $449.7635^{+2}(898.5197)$ & \\
\hline \multirow[t]{5}{*}{$\mathrm{C}$} & MAIPPKKN & k-casein & $449.7635^{+2}(898.5197)$ & 113 \\
\hline & QDKTEIPT & k-casein & $466.2745^{+2}(931.4801)$ & \\
\hline & LIVTQ & $\beta-L g$ & 573.3596 & \\
\hline & LTQTPV & $\beta$-casein & 658.3603 & \\
\hline & LDIQK & $\beta-\operatorname{Lg}$ & 616.3632 & \\
\hline
\end{tabular}




\section{Table 3}

Major peptides identified in hydrolysates produced from $\beta$-lactoglobulin after filtering the $2 \mathrm{~h}$ hydrolysate and extending the hydrolysis for 6 more hours by adding fresh enzyme (P3). Where: ** stands for peptides that was commonly found at $2+6 \mathrm{~h}$ $(\mathrm{E}: \mathrm{S}=1: 50)$ and $2+6 \mathrm{~h}(\mathrm{E}: \mathrm{S}=1: 100)$ and $\downarrow$ chymotrypsin, $\uparrow$ pepsin, $\rightarrow$ Trypsin digesting sites of the peptides.

\begin{tabular}{|c|c|c|c|c|c|}
\hline E: $S$ ratio & $\begin{array}{c}\text { Theoretical pepsin, } \\
\text { trypsin \& chymotrypsin } \\
\text { Cleavage site }\end{array}$ & $\begin{array}{l}\text { Protein } \\
\text { Source }\end{array}$ & $\begin{array}{c}\text { In silico } \\
\text { predicted ACE } \\
\text { inhibitors } \\
\end{array}$ & $\begin{array}{c}\text { Molecular } \\
\text { weight } \\
(\text { Da })^{\mathrm{a}} \\
\end{array}$ & $\begin{array}{c}\text { Isoelectric } \\
\text { point } \\
(\mathrm{Pi})^{\mathrm{a}}\end{array}$ \\
\hline \multirow[t]{10}{*}{ 1: 50} & $\mathrm{~F} \downarrow \uparrow \mathrm{K} / \mathrm{K} \uparrow \rightarrow \mathrm{F}$ & $\overline{\beta-L G}$ & & 294.188 & 8.75 \\
\hline & IIAE E* $^{*}$ & $\beta-L G$ & IA, IAE & 445.2656 & 4.6 \\
\hline & $\overline{\mathrm{IVTQ}}^{* *}$ & $\beta-L G$ & TQ & 460.2766 & 5.52 \\
\hline & $\mathrm{L} \downarrow \uparrow \mathrm{DAQ}$ & $\beta-L G$ & DA & 446.2245 & 3.8 \\
\hline & $\mathrm{L} \downarrow \uparrow \mathrm{IVT}^{* *}$ & $\beta-L G$ & & 445.302 & 5.52 \\
\hline & $\mathrm{L} \downarrow \uparrow I_{V T Q}^{* *}$ & $\beta-L G$ & TQ & 573.3606 & 5.52 \\
\hline & $\mathrm{R} \rightarrow \mathrm{L} / \mathrm{L} \downarrow \mathrm{R}^{* *}$ & $\beta-L G$ & RL & 288.203 & 9.75 \\
\hline & VAGT** & $\beta-L G$ & AG, GT & 347.1925 & 5.49 \\
\hline & $\mathrm{V} \uparrow \mathrm{F} \downarrow \uparrow \mathrm{K}$ & $\beta-L G$ & VF, VFK & 393.2496 & 8.72 \\
\hline & KPTPEGD $\uparrow L \downarrow \uparrow E I \uparrow L \downarrow \uparrow L^{* *}$ & $\beta-L G$ & $\begin{array}{c}\text { GD, EG, KP, EI, } \\
\text { PT }\end{array}$ & 1324.7358 & 4.14 \\
\hline 1: 100 & $\mathrm{IIAEK} \rightarrow \mathrm{T}$ & $\bar{\beta}-\overline{L G}$ & IA, IAE, EK & 674.4083 & 6 \\
\hline
\end{tabular}

${ }^{\mathrm{a}}$ is the isoelectric point of peptides from ExPASy proteomics tool and applied only for the peptides before digestion. 


\section{Table 4}

In silico digestion of the major peptides identified in the active fraction of the $2 \mathrm{~h}$ and $6 \mathrm{~h}$ hydrolysate permeated through the $1 \mathrm{kDa}$ ultrafiltration membrane (P1 and $\mathrm{P} 2)$.

Where: * stands for peptides that were common to both hydrolysates at 2 and $6 \mathrm{~h}$ and $\downarrow$ chymotrypsin, $\uparrow$ pepsin, $\rightarrow$ Trypsin are cleavage sites of these enzymes.

\begin{tabular}{|c|c|c|c|c|}
\hline $\begin{array}{l}\text { Hydrolysate } \\
\text { (h) }\end{array}$ & $\begin{array}{l}\text { Theoretical pepsin, trypsin \& } \\
\text { chymotrypsin Cleavage site }\end{array}$ & $\begin{array}{l}\text { In silico predicted } \\
\text { ACE inhibitors }\end{array}$ & 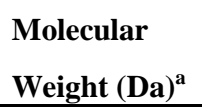 & $P i^{a}$ \\
\hline 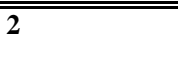 & $\mathrm{AM} \downarrow \mathrm{APK}$ & $\mathrm{AP}$ & 517.2803 & 8.80 \\
\hline \multirow[t]{22}{*}{$\mathrm{E}: \mathrm{S}=1: 100$} & $\begin{array}{l}\mathrm{H} \downarrow \mathrm{L} \uparrow \mathrm{P}^{*} / \mathrm{H} \downarrow \mathrm{IP} \\
\text { IASGEPT* }^{*}\end{array}$ & $\begin{array}{l}\text { HL } \\
\text { GEP, IA, GE, } \\
\text { SG, GEP, PT }\end{array}$ & $\begin{array}{l}365.2136 \\
674.3355\end{array}$ & $\begin{array}{l}6.75 \\
4.00\end{array}$ \\
\hline & $I P P^{*}$ & IPP, IP, PP & 326.2074 & $\begin{array}{l}5.52 \\
8.75\end{array}$ \\
\hline & $\mathrm{L} \downarrow \uparrow \mathrm{K} / \mathrm{I} \rightarrow \mathrm{K}^{*}$ & & 260.1968 & $\begin{array}{l}8.75 \\
8.75\end{array}$ \\
\hline & $\begin{array}{l}\mathrm{I} \rightarrow \mathrm{QK} / \mathrm{L} \downarrow \uparrow \mathrm{QK}^{*} \\
\mathrm{~K} \rightarrow \mathbf{I P A} *\end{array}$ & $\begin{array}{l}\text { QK, LQ } \\
\text { IPA, IP }\end{array}$ & $\begin{array}{l}388.2554 \\
428.2867\end{array}$ & $\begin{array}{l}8.75 \\
8.75\end{array}$ \\
\hline & $\mathrm{L} \downarrow \uparrow \mathrm{DIQK}^{*}$ & LDIQK, QK & 616.3664 & 5.84 \\
\hline & $\mathrm{L} \downarrow \uparrow I V T Q$ & TQ & 573.3606 & 5.52 \\
\hline & $\mathrm{L} \downarrow \mathrm{QPE}^{*}$ & LQP, LQ & 486.2558 & 4.60 \\
\hline & $\mathrm{L} \downarrow \uparrow \mathrm{R} * / \mathrm{R} \rightarrow \mathrm{L}^{*}$ & RL & 288.2030 & 9.75 \\
\hline & $\mathrm{L} \downarrow \mathrm{TQTP} *$ & TQ & 559.3086 & 5.52 \\
\hline & $\mathrm{L} \downarrow \uparrow \mathrm{TQTPV}$ & TQ, NIPPLTQTPV & 658.3770 & 5.52 \\
\hline & $\mathrm{M} \downarrow \mathrm{AIPPK} \rightarrow \mathrm{K} \rightarrow \mathrm{N}$ & $\begin{array}{l}\text { IPP, AIP, PK, IP, } \\
\text { PPK, AIPP, PP, AI }\end{array}$ & 896.5179 & 10.0 \\
\hline & $\mathrm{M} \downarrow \mathrm{APK}^{*}$ & $\overline{\mathbf{A P}}$ & 446.2431 & 8.50 \\
\hline & $\mathrm{PE}^{*}$ & & 245.1132 & 4.6 \\
\hline & $\mathrm{PH} \downarrow \mathrm{L}^{*}$ & HL, PH & 366.2136 & 7.17 \\
\hline & $\mathrm{PP}$ & PP & 213.1233 & \\
\hline & QDK $\rightarrow$ TEIPT* & IP, EI, TE, PT & 931.4731 & 4.37 \\
\hline & $\mathrm{TVK}^{*}$ & VK & 347.1925 & 5.19 \\
\hline & TVQVT* & & 547.3086 & 5.19 \\
\hline & $\mathrm{V} \downarrow \mathrm{F} \downarrow \uparrow \mathrm{K}$ & VF, VFK & 393.2496 & 8.72 \\
\hline & $\mathrm{VSK}^{*}$ & & 333.2132 & 8.72 \\
\hline & VTST & VTSTAV & 407.2136 & 5.49 \\
\hline & VQVT* & & 446.2609 & 5.49 \\
\hline 6 & $\mathrm{EK} \rightarrow \mathrm{VT}$ & EK & 476.2715 & 6.10 \\
\hline \multirow[t]{4}{*}{$E: S=1: 100$} & $\mathrm{~F} \downarrow \uparrow \rightarrow \mathrm{AQT}$ & & 466.2296 & 5.52 \\
\hline & $\mathrm{IIAEK} \rightarrow \mathrm{T}$ & IA, IAE, EK & 674.4083 & 6.00 \\
\hline & $\mathrm{K} \rightarrow \mathrm{VK} \rightarrow \mathrm{E}$ & VK, KE & 503.3187 & 8.59 \\
\hline & $\mathrm{SL} \uparrow \mathrm{PQN}$ & PQ & 558.2882 & 5.24 \\
\hline
\end{tabular}

${ }^{\mathrm{a}}$ Molecular weight and isoelectric points of peptides (before digestion) taken from ExPASy proteomics tool .

${ }^{\mathrm{b}}$ predicted peptide sequences using the BIOPEP software (http://www.uwm.edu.pl/biochemia/index_en.php). 


\section{Table 5}

Sensory discrimination of CDP derived hydrolysate; where CDP200, CDP300 and

CDP400 were hydrolysates of casein derived peptides at $200 \mu \mathrm{g} / \mathrm{mL}, 300 \mu \mathrm{g} / \mathrm{mL}$ and $400 \mu \mathrm{g} / \mathrm{mL}$ respectively. $\mathrm{N}$ is number of panellists.

\begin{tabular}{|c|c|c|c|c|c|c|}
\hline Samples & $\mathrm{N}$ & $\begin{array}{c}\text { Number of } \\
\text { correctly } \\
\text { identified } \\
\text { samples } \\
\end{array}$ & $\begin{array}{l}\text { Significance } \\
(\mathrm{p} \text { value })^{\mathrm{a}}\end{array}$ & $\begin{array}{c}\text { Proportion of } \\
\text { discriminators }\end{array}$ & $\begin{array}{l}\text { Upper } \\
\text { bound }^{\mathrm{c}}\end{array}$ & $\begin{array}{c}\text { Probability } \\
\text { of obtaining } \\
\text { a higher } \\
\text { upper } \\
\text { bound }^{\mathrm{d}} \\
\end{array}$ \\
\hline CDP200 & 39 & 18 & 0.066 & 0.406 & 0.604 & 0.033 \\
\hline CDP300 & 39 & 13 & 0.56 & 0.215 & 0.477 & 0.425 \\
\hline CDP400 & 39 & 13 & 0.56 & 0.215 & 0.477 & 0.425 \\
\hline
\end{tabular}

${ }^{\text {a }}$ Type I error : risk of finding a false difference

${ }^{b}$ The maximum acceptable proportion of the population that can distinguish between the samples (typically an acceptable maximum set at 0.3 or $30 \%$ )

${ }^{\mathrm{c}}$ The upper bound is the probability of a correct trial

${ }^{d}$ The probability of obtaining a higher upper bound value in 39 trials (i.e. of obtaining a less satisifactory result) 


\section{Table 6}

Sensory discrimination of $\beta$-lactoglobulin derived hydrolysate; where $\beta$-LG100, $\beta$ -

LG150 and $\beta$-LG200 were $100 \mu \mathrm{g} / \mathrm{mL}, 150 \mu \mathrm{g} / \mathrm{mL}$ and $200 \mu \mathrm{g} / \mathrm{mL}$ respectively. $\mathrm{N}$ is number of panellists.

\begin{tabular}{ccccccc}
\hline \hline & $\begin{array}{c}\text { Number of } \\
\text { Correctly } \\
\text { identified } \\
\text { samples }\end{array}$ & $\begin{array}{c}\text { Significance } \\
(\mathrm{p} \text { value) }\end{array}$ & $\begin{array}{c}\text { Proportion of } \\
\text { discriminators }^{\mathrm{b}}\end{array}$ & $\begin{array}{c}\text { Upper } \\
\text { bound }^{\mathrm{c}}\end{array}$ & $\begin{array}{c}\text { Probability } \\
\text { of obtaining } \\
\text { a higher } \\
\text { upper } \\
\text { bound }^{\mathrm{d}}\end{array}$ \\
\hline \hline$\beta$-LG100 & 39 & 10 & 0.885 & 0.094 & 0.396 & 0.80 \\
$\beta$-LG150 & 39 & 16 & 0.196 & 0.332 & 0.555 & 0.118 \\
$\beta$-LG200 & 39 & 17 & 0.118 & 0.369 & 0.579 & 0.066 \\
\hline \hline
\end{tabular}

${ }^{\mathrm{a}}$ Type I error : risk of finding a false difference

${ }^{b}$ The maximum acceptable proportion of the population that can distinguish between the samples (typically an acceptable maximum set at 0.3 or $30 \%$ )

${ }^{c}$ The upper bound is the probability of a correct trial

${ }^{\mathrm{d}}$ The probability of obtaining a higher upper bound value in 39 trials (ie of obtaining a less satisifactory result) 
FIGURES: 


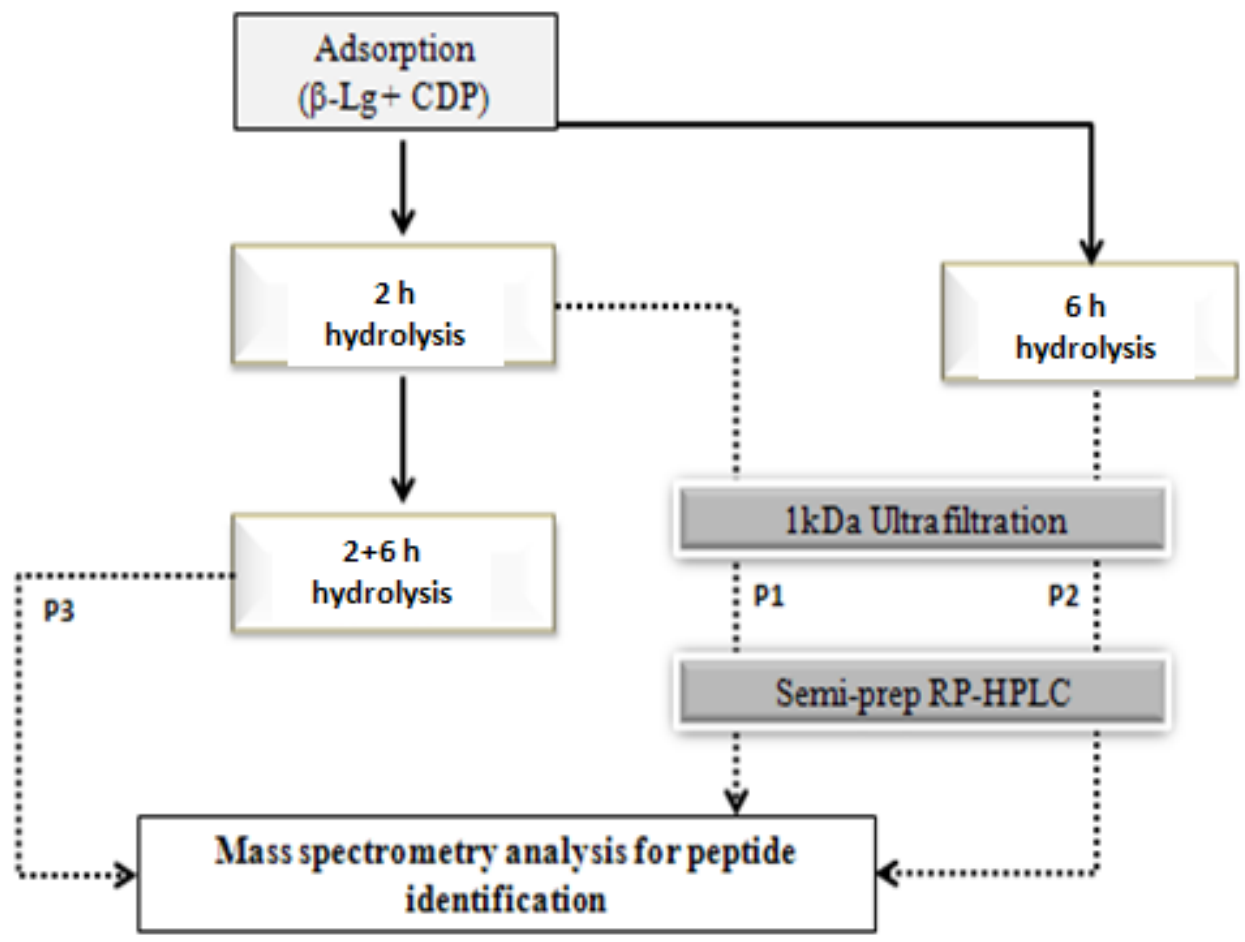

Figure 1 


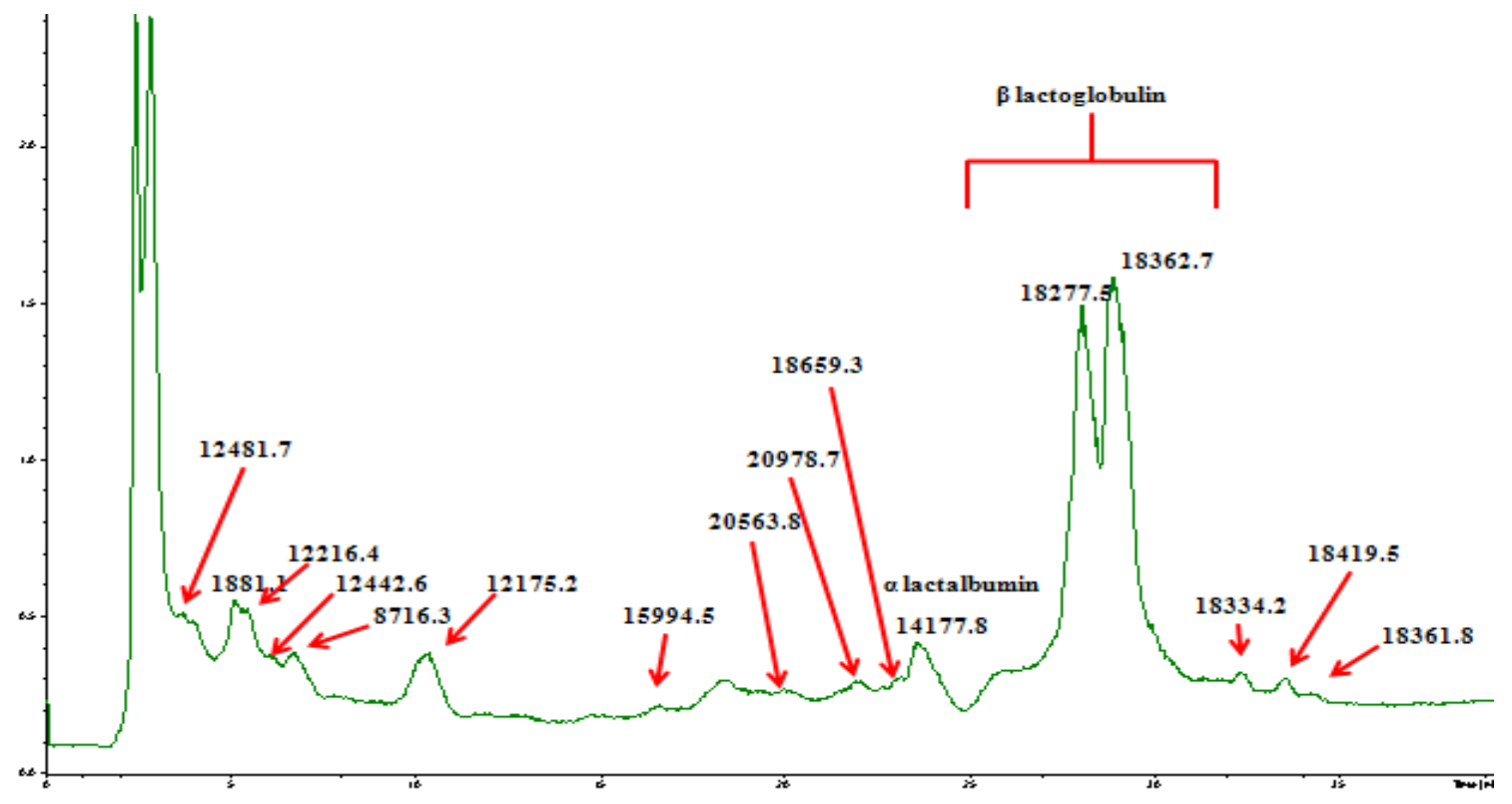

Figure 2 


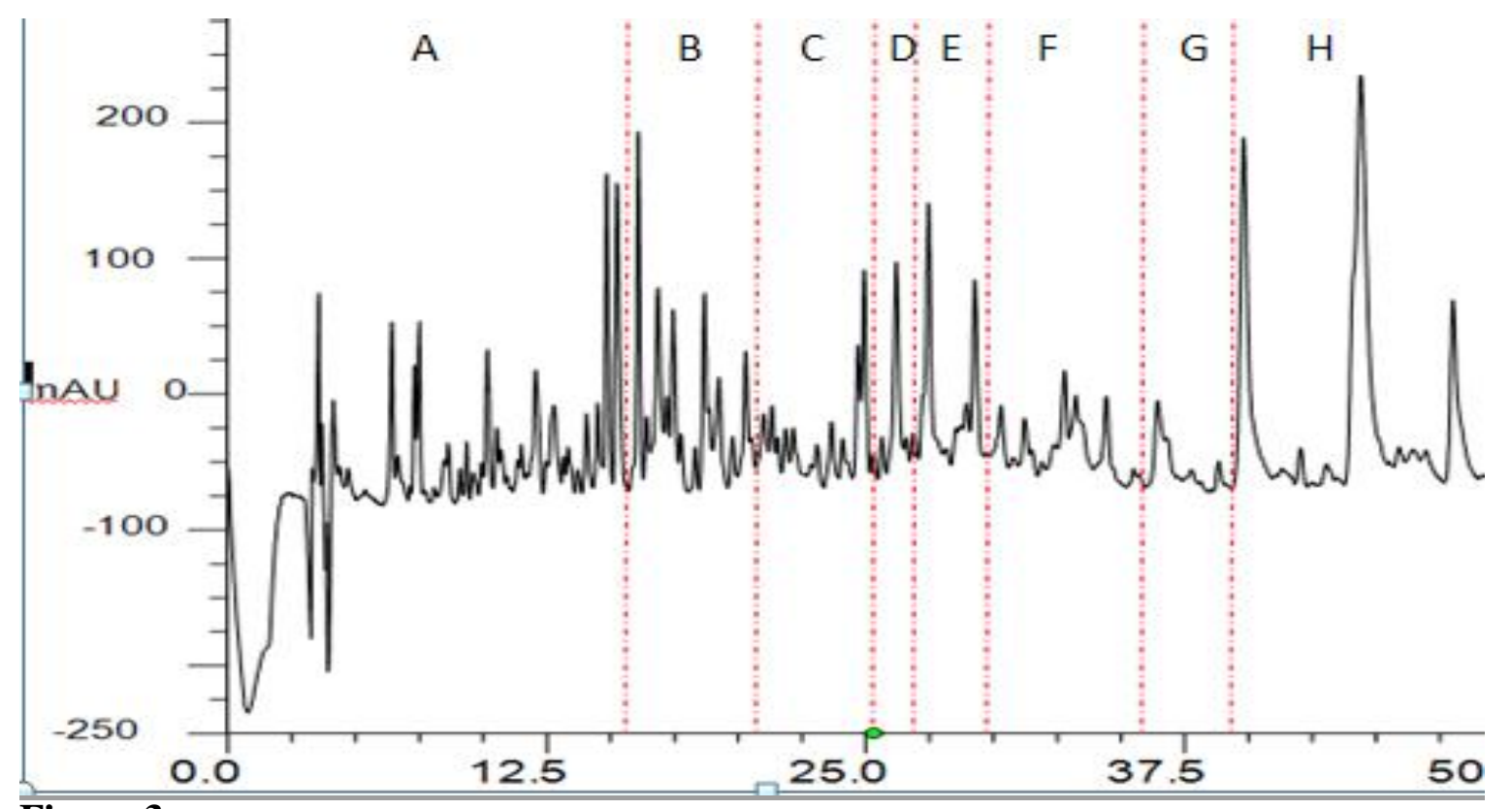

Figure 3 


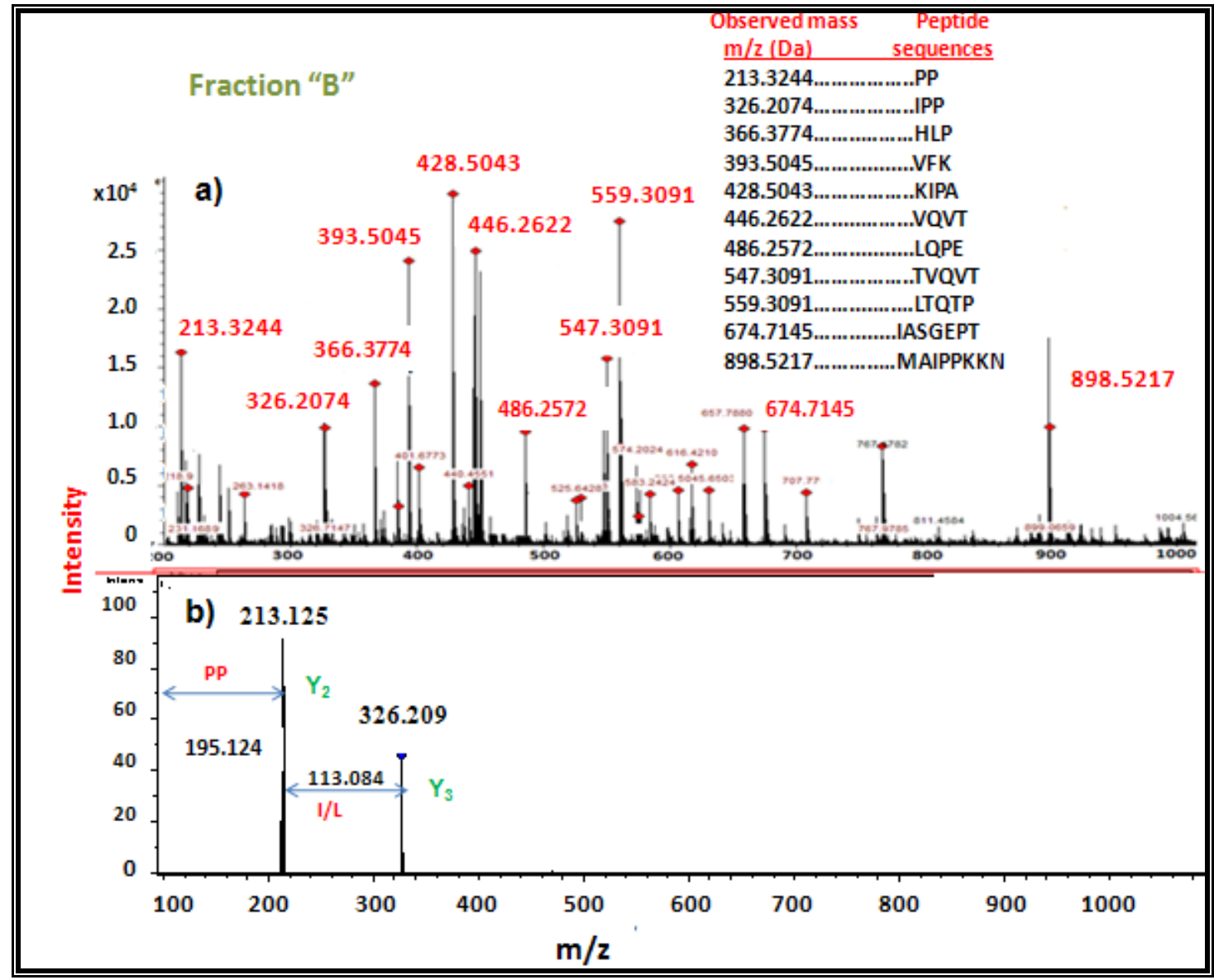

Figure 4 


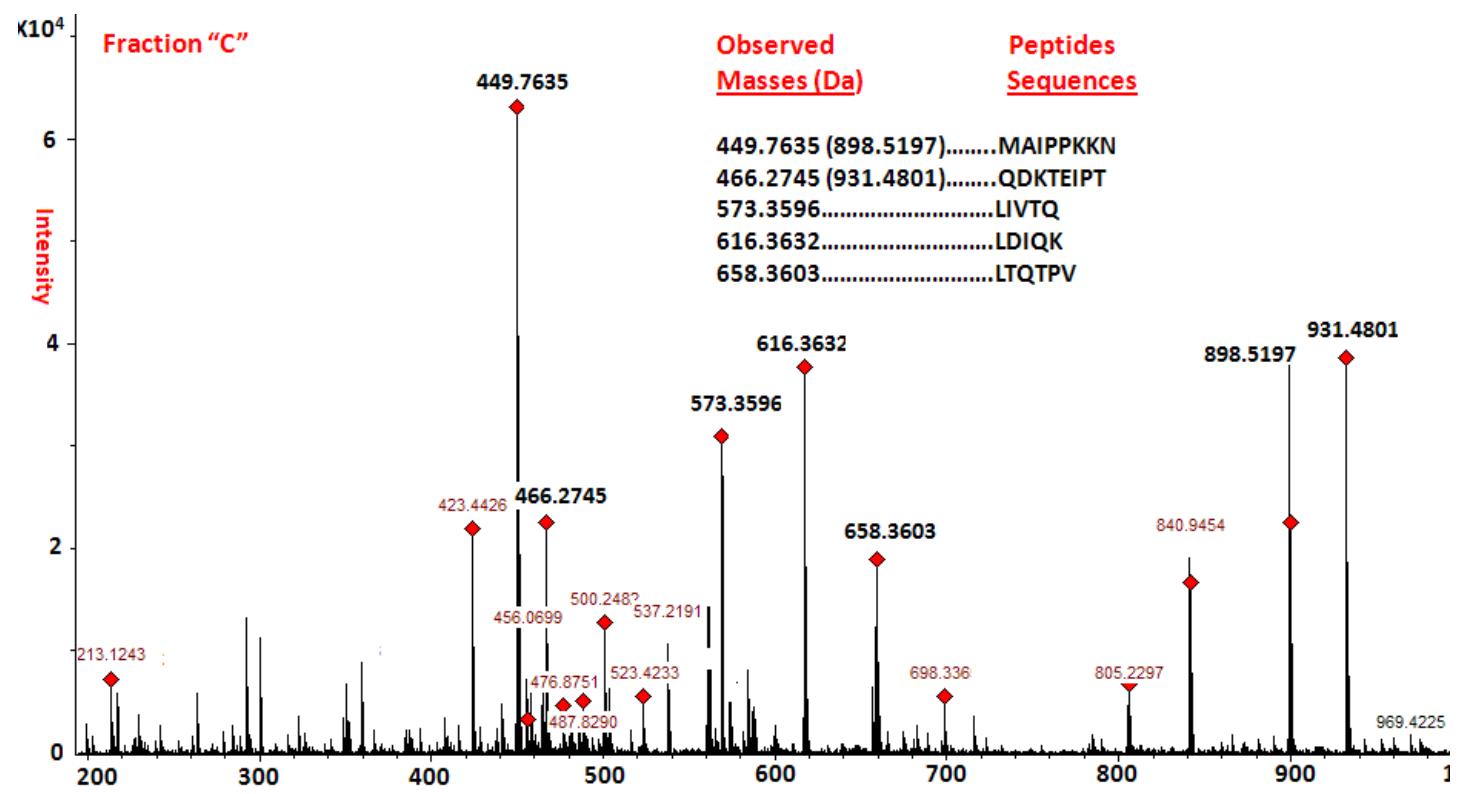

Figure 5 


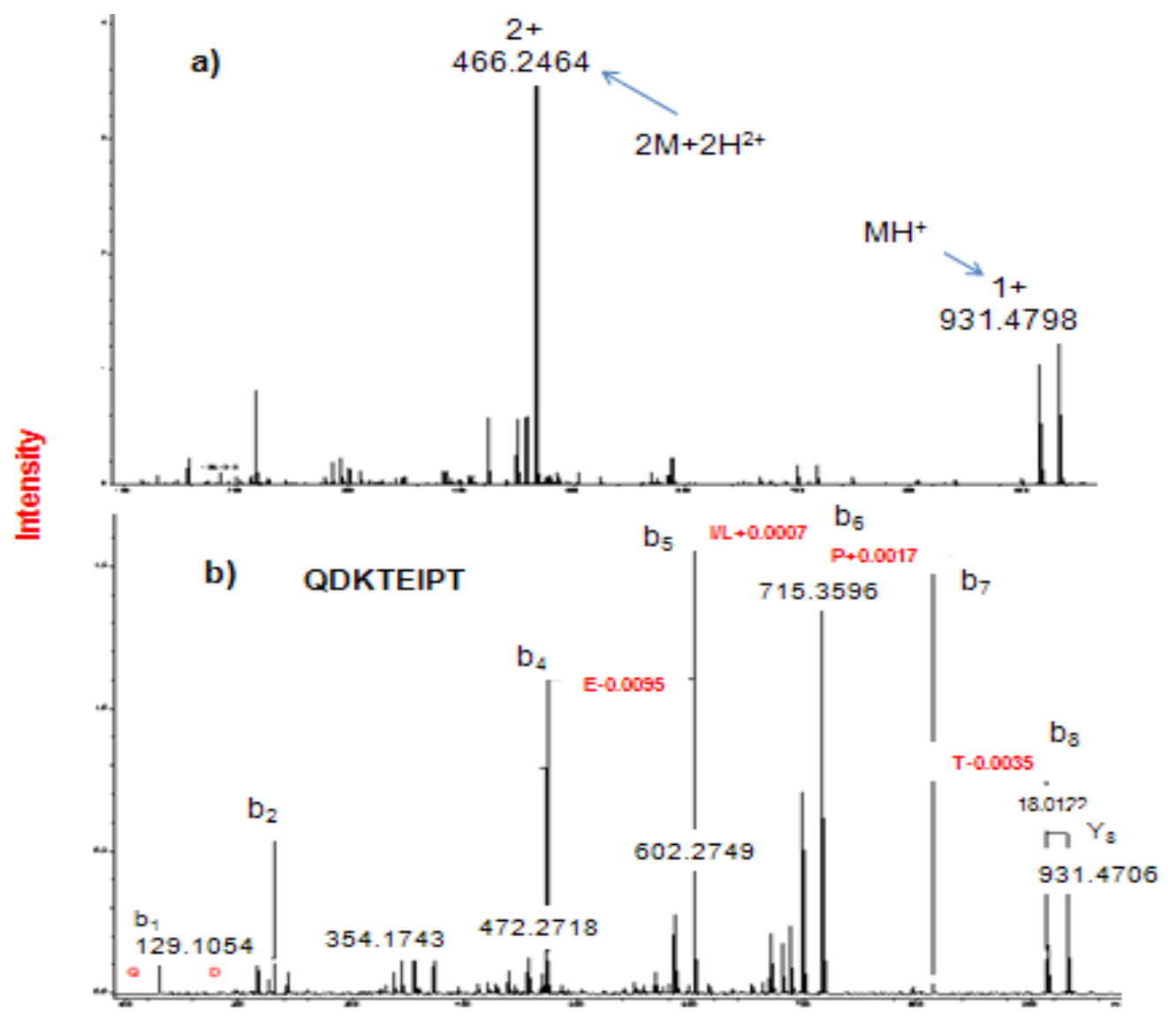

Figure 6 
Fraction "A"

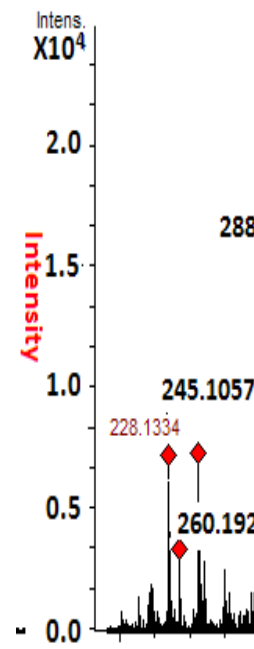

200

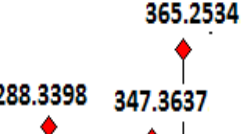

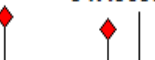

333.3596

$\left\langle\left.\right|_{362.2410} \quad 446.5118\right.$

517.4536

329.5705 औै 418.1391

$\begin{array}{lll}358.1511 & 418.1391\end{array}$

$\mid \begin{array}{r}388.2503 \\ ||^{3}\end{array}$
Observed

Masses (Da)

245.1057

260.1928

288.3398 .

333.3596 .

347.3637

365.2534

388.2582 .

446.5118 .

486.2502 .

517.4536 .

${ }^{707} 723.1998767 .8005$
Peptides

Sequences

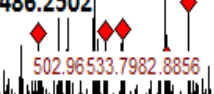

500

600
PE

.L/IK

..L/R

VSK

MAPK

LQPE

AMAPK

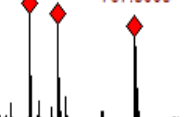

Figure 7 


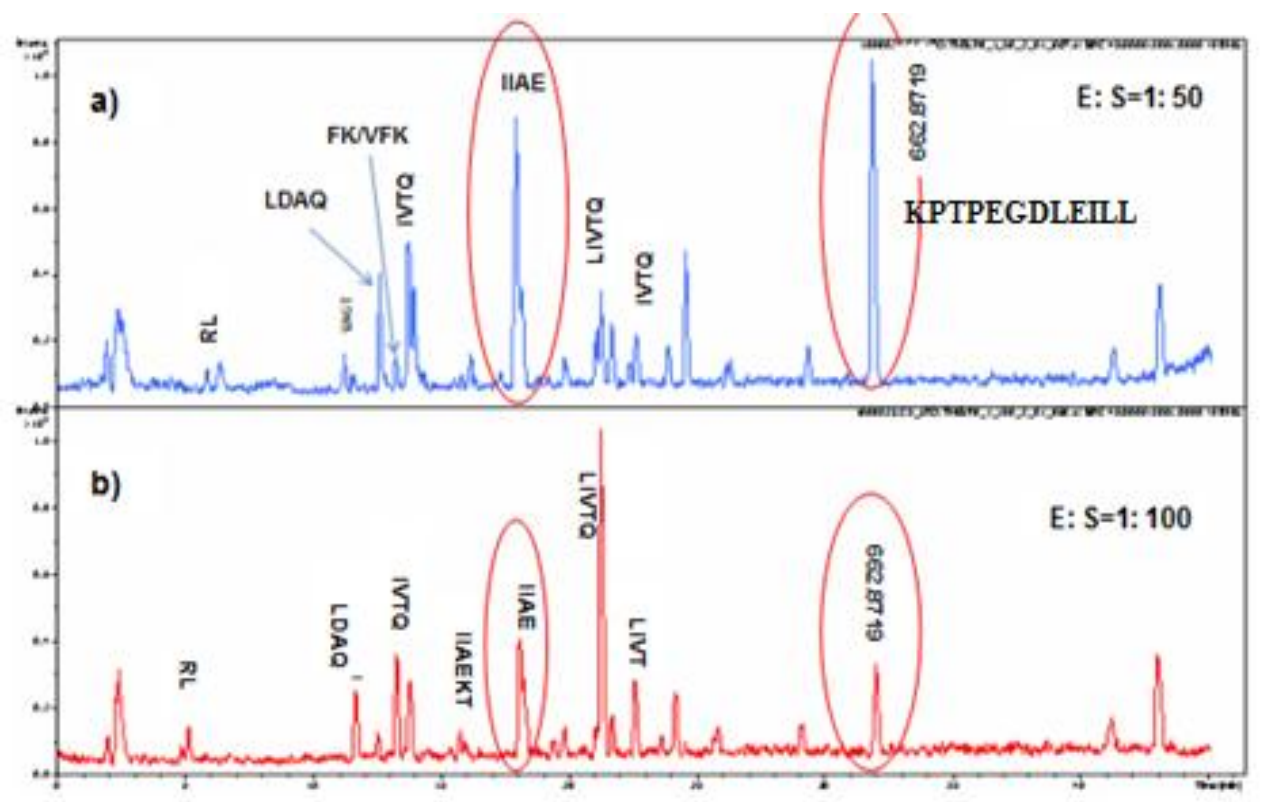

Figure 8 


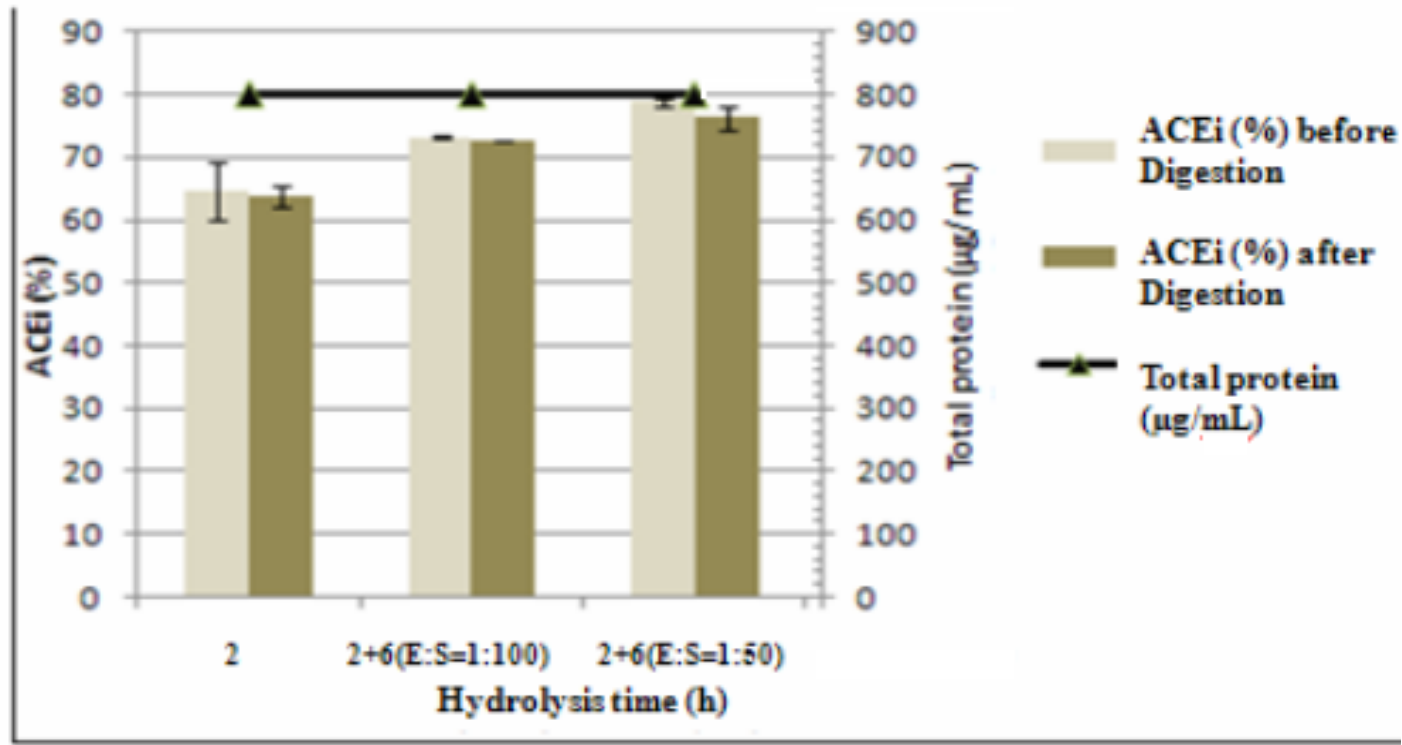

Figure 9 